\title{
CONTRIBUTIONS TO BIOLOGY
}

FROM

THE HOPKINS SEASIDE LABORATORY

OF THE

LELAND STANFORD JR. UNIVERSITY

$\mathbf{X X} \mathbf{X I}$

\section{The Development and Phylogeny of Placenticeras}

James Perrin Smith

Stanford Unizersity, California 3d Ser., Geology, Vol. I]

Palo Alto, California

I900 


\section{University Publications.}

\section{HISTORY AND ECONOMICS.}

1. The Tariff Controversy in the United States, 17891833. With a Summary of the Period before the Adoption of the Constitution. By OrRin Leslie Elliott, Ph. D. pp. 272.

2. Official Relations between the United States and the Sioux Indians. By Lucy Elizabeth Textor, A. M. pp. I6o.

3. Almshouse Women: A Study of 228 Women in the City and County Almshouse of San Francisco. By MARY Roberts Smith, Ph. D. pp. $44+12$ pp. tables.

\section{ELECTRICITY.}

Observations on the Conductivity of a Copper Wire in Various Dielectrics. By Fernando SAnford, M. S. pp. 44.

GEOLOGY AND PALEONTOLOGY.

The Neocene Stratigraphy of the Santa Cruz Mountains of California. By George H. Ashley. pp. 95.4 plates.

THE HOPKINS LABORATORY.

1. The Fishes of Sinaloa. By David Starr Jordan. pp. I42. 29 plates.

2. On the Cranial Characters of the Genus Sebastodes. By Frank Cramer. pp. 42. I4 plates.

3. The Fishes of Puget Sound. By David S. Jordan and Edwin C. Stariks. pp. 7r. 29 plates.

4. New Mallophaga, I, with special reference to a Collection made from Maritime Birds of the Bay of Monterey, California. By VERnon L. KELLOGG. pp. I44. I 5 plates.

5. Notes on Fishes, Little Known or New to Science. By David StarR Jordan. pp. 48.24 plates.

6. Notes on Fresh Water Fishes of the Pacific Slope of North America. By Cloudsley Rutter. With Description of a New Species of Pipe-Fish (Siphostoma sinaloæ) from Mazatlan. By DAvid S. Jordan and Edwin C. Stariks. And Notes on Deltistes, a New Genus of Catostomoid Fishes. By Alvin Seale. pp. 29.

7. New Mallophaga, II, from Land Birds, together with an account of the Mallophagous Mouth-Parts. By Vernon L. Kellogg. pp. II8. I4 plates.

8. List of Fishes Collected at Port Ludlow, Wash. By EDwin Chapin StaRks. pp. I4. 2 plates.

9. Marine Fossils from the Coal Measures of Arkansas. By James Perrin Smith. pp. 72. 9 plates.

10. Scientific Names of Greek and Latin Derivation. By Walter Miller. pp. 3r.

11. A Morphological Study of Naias and Zannichellia. By Douglas Houghton Campbell. pp. 68.5 plates. 


\section{CONTRIBUTIONS TO BIOLOGY FROM}

\section{The Hopkins Seaside LabORatory}

$$
\text { OF THE }
$$

LELAND STANFORD JR. UNIVERSITY

$\mathbf{X X I}$

\section{The Development and Phylogeny of Placenticeras}

BY

James Perrin Smith

Stanford University, California

[Reprinted from the Proceedings of the California Academy of Sciences 3d Ser., Geology, Vol. I] 


\section{Digitized by the Internet Archive in 2017 with funding from}

University of Illinois Urbana-Champaign Alternates 


\section{PREFATORY NOTE.}

This memoir is the twenty-second of a series designed to illustrate investigations and explorations connected with the Hopkins Seaside Laboratory, an adjunct of the biological laboratories of the Leland Stanford Junior University. These investigations have been carried on by means of the assistance given by Timothy Hopkins, Esq., of Menlo Park, California. This memoir appears in the publications of the California Academy of Sciences, the present edition being a reprint.

Oliver P. Jenkins,

Charles H. Gilbert,

Directors Hopkins Laboratory.

Date of publication, Aug. I5, I90o. 



\title{
THE DEVELOPMENT AND PHYLOGENY OF PLACENTICERAS.
}

\author{
BY JAMES PERRIN SMITH. \\ Stanford University, California.
}

\section{CONTENTS.}

Plates XXIV-XXVIII.

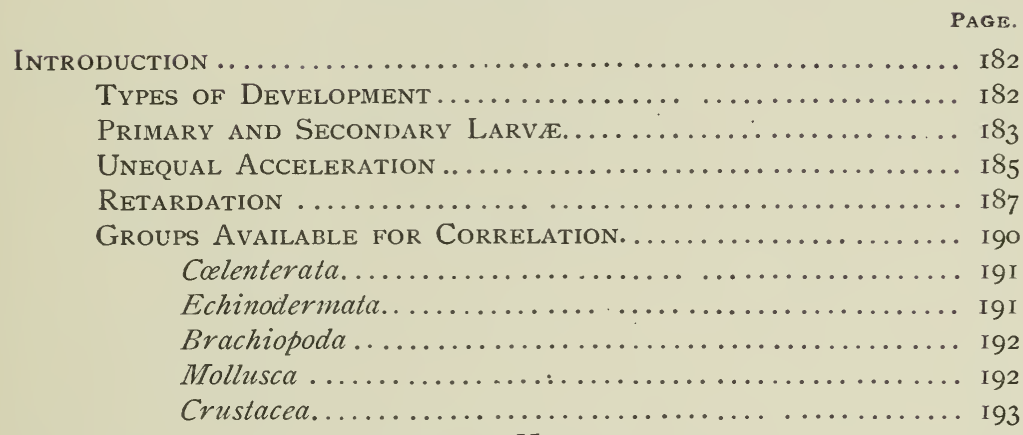

Affinities of Placenticeras and Hoplites. . . . . . . . . . . . 193

Phylogenic Table of Placenticeras and Associated Genera 202 Placenticeras californicum ANDERSON (MS.) ............... 203

LARval And Adolescent Stages ................... 205

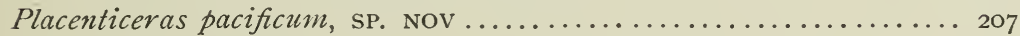

Larval Stages ................................. 2 Io

Phylembryonic Stage..................... 2 10

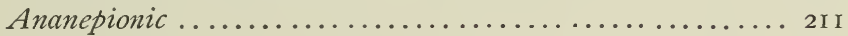

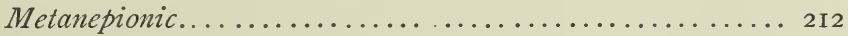

Paranepionic ........................... 213

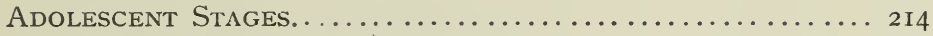

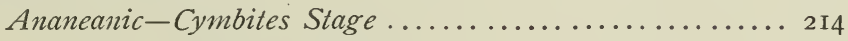

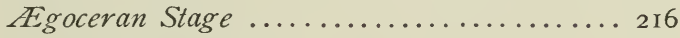

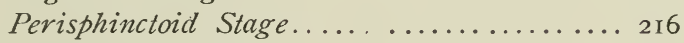

Metaneanic-Cosmoceras Stage............... 217

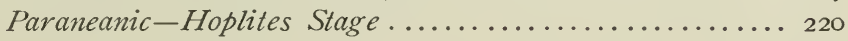

Ephebic or Adult Stage.......................... 22 I

Table of Cross-section of Placenticeras pacificum . . . . . 224

Table of Stages of Growth of Placenticeras pacificum. 224 Conclusion and Summary of Results ................. 226

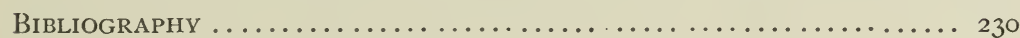

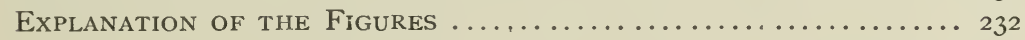




\section{INTRODUCTION.}

THE interest of the paleontologist in embryology, and in ontogeny in general, lies wholly in the desire to know the origin and relationships of biologic groups. A scientific interpretation of ontogenic data in terms of phylogeny depends on the extent of preservation of the ancestral record in individual development. The broad statement has often been made that each animal gives in its own development an epitome of the history of its race. Because of the law of heredity, this statementwould be true, and the record would be complete, if nothing had interfered with the normal course of things. But, in reality, so many secondary elements are introduced in development, that authorities are very much divided as to the value of ontogenic stages as records of race history. ${ }^{1}$

There can be no doubt that students of postembryonic stages have been inclined to claim too much for the law of tachygenesis, while, on the other hand, students of embryology have been inclined to discredit it almost entirely, and to lay little stress on ontogenic stages as a recapitulation of phylogeny. The reason for this disagreement is not far to seek; it lies in the field and in the methods of research of the two groups of morphologists.

Types of Development.-Leaving out of consideration the Protozoa, which come into being with the essential characteristics of the adults, there are, in the Metazoa, two types of development: (I) the fatal type, in which development takes place in the egg, or in the body of the parent, and the young animal comes into the world in form closely resembling the adult; (2) the larval type, in which the young animal comes out at an earlier stage of development, and reaches maturity only after considerable metamorphosis.

Secondary elements will be introduced in either type of development, and those variations that are favorable to the

\footnotetext{
${ }^{1}$ In the preparation of this Introduction the writer has drawn largely on Balfour's "Treatise on Comparative Fimbryology," and on Lang's "Comparative Anatomy."
} 
preservation of the species are likely to be perpetuated by heredity. Now in the fœtal type the most favorable variation consists in abbreviation, thus simplifying the development. Any characters that are useful in a free state, but not in a fœtal state, are liable to be lost. Thus in the fœtal type the tendency is towards loss of the record through omission of stages or obscuring them, for many organs that would be highly developed in mature forms, or in free larvæ, will be either suppressed or undifferentiated.

The vertebrates, most of the higher crustaceans, most land and fresh-water molluscs ${ }^{1}$ have the fœtal type of development; and these embrace by far the larger part of animals whose ontogeny has been studied. It is not to be wondered at, then, that morphologists who deal exclusively with embryonic stages of these groups should be sceptical about the repetition of family history in individual development. Here many stages are omitted, and the rest so obscured and undifferentiated as to be unintelligible; and secondary characters, due to life in the egg or in the parent, are introduced, effacing what little meaning was left. Then, too, embryologists are often content to trace the animal but a little way toward perfection of development; they study the embryo until the cells begin to divide into groups indicating a beginning of organs, and call this studying ontogeny, when they have stopped before it could be told whether the animal was going to develop into fish, flesh, or fowl. To this sort of study is due the idea of "falsification of the record," a crime of which nature has not yet been guilty, although she at times may not, perhaps, have told the whole truth.

Primary and Secondary Larva.-If the way of the embryologist lies in stony places, that of the student of postembryonic stages is not much smoother; formidable obstacles meet him on every side, reducing his small stock of faith. At the very outset he is confronted by the difficulty that there are two distinct types of larvæ: (a) primary

1 Dreissensia, a fresh-water pelecypod, which in very recent geologic time has immigrated from salt-water, still goes through its larval development, like its marine relatives. 
larva, such as are more or less modified from ancestral forms, and have continued to develop as free larvæ since the time when they constituted the adult forms; (b) secondary larva, such as have been introduced by kenogenesis into the ontogeny of species that formerly developed by the fœtal process. If ancestral characters have been retained in the egg, then these secondary larvæ may bear some palingenetic characters, and thus be hard to distinguish from primary larvæ; otherwise they will be entirely adaptive, or kenogenetic. A case in point is the development of most insects, whose larval stages are supposed to be entirely secondary. Study of individual development in a group of this sort can throw no light on phylogeny.

The student of larval stages must confine himself to the primary sort, if he would correlate them with ancestral genera. The development of the cœlenterates, echinoderms, brachiopods, most molluscs, and the lower crustaceans is direct; thus larval stages of these groups may be bearers, to a greater or less degree, of ancestral characters. But since the free larvæ of even these groups are exposed to natural selection, secondary or kenogenetic characters will be introduced, obscuring the resemblance to ancestral forms; also characters that in the adult ancestral form were functional and fully developed may in the representative larval stage of the descendant be so little differentiated as to be unrecognizable.

But how can the morphologist who deals entirely with living species know whether a character is primary, and repeated by palingenesis in the larval history of the descendant, or whether it is secondary, and introduced by kenogenesis into that history? The answer to this lies wholly within the domain of paleontology, for only by finding a stage of growth represented by an ancestral form can the morphologist know that the characters of that stage are ancestral, and not secondary. Larval stages which may be the bearers of ancestral characters must then be compared with the adults of their predecessors, and the paleontologic record must be invoked as a final resort-the court from which there is no appeal. 
And this was exactly the method used by Louis Agassiz, who first applied the law of acceleration of development to the study of systematic zoology, although it never had much influence on biologic investigation until the paleontologic studies of Hyatt ( 1872 ) in the invertebrates, and Cope in the vertebrates placed the law on a sound basis. It was reserved for Alpheus Hyatt ( I866) to formulate the law, and to strengthen theory with practical examples based on study of Cephalopoda. In his later papers Professor Hyatt (I889, preface, p. ix) has given a more exact and comprehensive definition of the law of acceleration or tachygenesis: "All modifications and variations in progressive series tend to appear first in the adolescent or adult stages of growth, and then to be inherited in successive descendants at earlier and earlier stages according to the law of acceleration, until they either become embryonic, or are crowded out of the organization, and replaced in the development by characteristics of later origin." A still more definite statement by the same author (Hyatt, r894) is the following: "The substages of development in ontogeny are the bearers of distal ancestral characters in inverse proportion and of proximal ancestral characters in direct proportion to their removal in time and position from the protoconch or last embryonic stage."

To insure trustworthy results in verifying this law, the investigator must have groups in which the larvæ are primary and reproduce ancestral characters; in which the living and the fossil are classified on the same basis; of which we have preserved a nearly complete geologic record; and of which material is available for the study of fossil ontogeny as a check on the living. Such groups are especially represented among the Colenterata, the Echinodermata, the Brachiopoda, and the Pelecypoda and Cephalopoda among the molluscs.

Unequal Acceleration.-Now, when the morphologist has settled the fact that primary larval stages do actually reproduce, more or less vaguely, characters that existed in the adult forefathers of the generation he is at work on, his troubles are even then not yet ended; for the characters do 
not necessarily appear in the ontogeny of the descendant in the same association in which they occurred in the ancestor. A character useful to the immature form will have a tendency to be inherited at an earlier age than those useful only to the adult, and so by unequal acceleration of development the parallel between ontogeny and phylogeny is broken. It was once thought that the Nauplius larva of the crustaceans was a mature genus, then it was thought to be a larval representative of the extinct radicle of the Crustacea; later still, many morphologists have concluded that the Nauplius, while it bears many crustacean characters, still retains too many annelid characters to represent the radicle of the group; it is a typical crustacean larva, but not a representative of the primitive crustacean, and the two sets of characters are thrown together by unequal acceleration. Beecher (I895, p. I73, Pl. IX, figs. I, 2, 4) has shown the same thing in the spiny larvæ of Acidaspis and Arges, where in the protaspis of these genera the spines characteristic of the adults appear, contrary to usage among the trilobites, in which larval stages are usually smooth. Thus before these animals have assumed characters that would identify them undoubtedly with trilobites they have assumed those most characteristic of their own genera. Jackson (I89o, p. 38I) has shown that in the larvæ of the Pectinidae unequal acceleration may associate characters that were not synchronous in race history. F. Bernard ( $1896-97$ ) has recently shown that the prodissoconch of pelecypods is sometimes striated and ribbed, characters that could not have belonged to the primitive pelecypod.

If unequal acceleration causes confusion in the phylembryonic stages, the difficulty is much greater in the larval and adolescent periods, where the shortness of the time of development causes throwing together of characters that were not contemporaneous in the ancestors, and where the small size and general habits prevent differentiation of organs that in the correlative adult forms were highly developed, thus obscuring and even destroying the exactness of the parallelism. 
The two species of Placenticeras, of which the ontogeny is described in this paper, must have descended not only from the same perisphinctoid family, but also from the same species of Hoplites; and thus if the parallel were at all exact, they should be alike in the late adolescent stages, when they begin to show their generic characters. This, however, is not the case, for they are quite different throughout the cosmoceran stage, and back almost to the end of the larval period, where the transition from goniatite to ammonite took place. If this were interpreted without taking account of unequal acceleration, it would seem that the differentiation of the two species took place back in the Trias, and that different ægoceran forms were the remote ancestors of the two species, which we know could not have been the case.

The writer (I899) has recently worked out the ontogeny of two very nearly related species of Schlonbachia, one of which, in its larval period, reproduces very exactly a Paralegoceras stage, while the other does not; the latter species has, however, all the paralegoceran characters, but associated with others that this genus never had, but which belonged to later descendants of this genus. There can be here no question of the veracity of nature in keeping the record, the difficulty lies in deciphering it. So it is not to be expected that any one species would give in plain terms the complete phylogeny of a genus, for stages that are plainly differentiated in one will be obscured in another, and only by studying the ontogeny of a number of species of one genus can the morphologist hope to get a complete history.

Retardation.-Another factor that makes it difficult to correlate ontogeny and phylogeny is retardation of development. Cope first recognized the principle, but in his writings confused it with unequal acceleration, and since his reasoning was purely theoretical the idea has never gained much foothold in biologic philosophy. Cope's statement (I887, p. $1_{42}$ ) of the theory is as follows: "The acceleration in the assumption of a character, progressing more rapidly than the same in another character, must soon produce, in a type 
whose stages were once the exact parallel of a permanent lower form, the condition of inexact parallelism. As all the more comprehensive groups present this relation to each other, we are compelled to believe that acceleration has been the principle of their successive evolution during the long ages of geologic time. Each type has, however, its day of supremacy and perfection of organism, and a retrogression in these respects has succeeded. This has, no doubt, followed a law the reverse of acceleration, which has been called retardation. By the increasing slowness of the growth of the individuals of a genus, and later and later assumption of the characters of the latter, they would be successively lost." This statement of Cope might apply equally well to unequal acceleration of characters, but in a nother part of this same work he gives a clearer statement: "Where characters which appear latest in embryonic history are lost, we have simple retardation, that is, the animal in successive generations fails to grow up to the highest point of completion, falling further and further back, thus presenting an increasingly slower growth in the special direction in question." (Cope, I887, p. I3.)

These remarks of Cope were based on abstract reasoning, but it is possible to bring up some striking cases in support of the theory, notably among the brachiopods. Fischer and Oehlert ( 1892 ) have shown that while brachiopods go through many metamorphoses in individual evolution, and while each species is usually constant in the stages it goes through, it often happens that the individual is arrested in development, never reaching the full generic development of the mature stage. The individual then begins to reproduce its kind before maturity is reached, and tends to give rise to a stock that never reaches the full generic evolution of its ancestors. Dr. C. E. Beecher ( $1893 b$ ) has well described this: "In each line of progression in the Terebratellidæ the acceleration of the period of reproduction, by influence of environment, threw off genera which did not go through the complete series of metamorphoses, but are otherwise fully adult, and even may show reversional tendencies due to old age; so that nearly 
every stage passed through by the higher genera has a fixed representative in a lower genus. Moreover, the lower genera are not merely equivalent to, or in exact parallelism with, the early stages of the higher, but they express a permanent type of structure, so far as these genera are concerned, and after reaching maturity do not show a tendency to attain higher phases of development, but thicken the shell and cardinal process, absorb the deltidial plates, and exhibit all the evidences of senility."

If, then, the morphologist tries to study the race history in one of these species thus arrested in development, he can not read the whole story, for the individual ontogeny will not recapitulate the higher stages lost by retardation.

Another remarkable case is that of the so-called "ceratites" of the Cretaceous. While there have been no goniatites since the Paleozoic, and no ceratites since the Trias, there are found among the ammonites of the Cretaceous some with septa of simple goniatitic character, and others with septa like those of the genuine ceratites. Now since the line of descent is broken and there is no possibility for a continuous line of these ancient primitive forms to have bridged over the great gap from the Trias to the Upper Cretaceous, we must explain this either by reversion, or in some other way. But it is not a simple case of reversion, for, as has been pointed out by several writers (Douvillé, I890, pp. 275-292; Nicklès, I890), the septum of adolescent ammonites of this group is not more complex, but really less so, than that of adults, although they are derived from Jurassic genera with complex septa. Thus Douvillé, in the paper cited above, derives the group Placenticeras-Sphenodiscus from Hoplites; the Pulchellidæ, composed of Pulchellia, Neolobites, and Tissotia, he derives from Oppelia of the Jura. Since in each case the ancestral forms are more complex than the descendants, the reduction in complexity of generic evolution can be explained only by retardation, or arrested development. F. Bernard ( 1895, p. 668) has, in addition, pointed out the fact that the adult of Pulchellia is like the adolescent stage of the ancestral Oppelic. Now, if 
we define the law of acceleration of development to mean that in a progressive series the young of the descendants correspond to the adults of their more remote ancestors, we find that this does not apply to a retrogressive (retarded) series. In this latter case we must restate the law as follows: The adults of descendants correspond to the young of their more remote ancestors, the higher generic stages to which these ancestors attained having been dropped away by successive retardation, or arrested development. The retarded series themselves may become the radicles of new stocks, and so we may have cases where the ontogeny of any one species or genus can never give the full history of the race.

Groups Available for Correlation.-We see, then, that the student of morphogeny of animals has to be on his guard, first against the loss of generic stages during the period while the animal is in the egg; then against the introduction of secondary larval stages when the ancestors lacked them; then against the introduction of secondary characters due to adaptation; then against unequal acceleration, bringing together, in the ontogeny of the descendant, characters that occurred in separate generations of ancestors; and lastly, against retardation, by which the form never reaches the full generic evolution of its ancestors, and where, if a new series starts out from the retarded form, the complete family history is not recorded in ontogeny.

Is it to be wondered at, then, that the student of morphology becomes a sceptic, or even a rank unbeliever with regard to the value of ontogenic stages as records of history? It is only to be expected that the biologist, especially one that deals almost exclusively with living species, should be inclined to discredit the law of tachygenesis, and to believe that there is such an inextricable muddle of omissions, secondarily introduced characters, and unequal acceleration of those actually repeated, that the record is wholly untrustworthy, or at least illegible. And yet there are so many species and genera in the various groups of invertebrates whose ontogeny is simple, progressive and fairly 
complete, and whose stages of growth are almost exact repetitions of successive antecedent genera, that it would be impossible to find a student of the morphogeny of the brachiopods, the marine molluscs, or the lower crustaceans, that does not believe implicitly in the value of larval stages of these groups as records of their family history. And this is especially true of the paleobiologists, who regard it of little importance whether the animal under investigation died yesterday, during the Flood, or during the Paleozoic era, whether it is preserved in alcohol or in a more permanent museum in the bosom of Mother Earth; they recognize the fact that the laws that govern the rise and decline of organisms were just as true then as now, and that the life-history of a Cambrian trilobite has as much bearing on modern biology as does the history of the living cray-fish.

Not all groups are equally useful to the student of morphogeny, but in each of the lower subkingdoms there are genera of which the ontogeny has been worked out and correlated in no uncertain terms with the history of the race. The testimony of these various groups is so uniform, notwithstanding the fact of its having been gathered by men of different beliefs, that its value can not be doubted. It is also noteworthy that in the higher groups, such as cephalopods and crustaceans, the evidence and the correlations are much more decided.

Colenterata.-It has been shown by Dr. C. E. Beecher (I89I) that the young stages of the Favositidæ correspond to Aulopora, or to some other similar unspecialized genus. This same conclusion has been reached by Dr. G. H. Girty (1895) based on a study of the ontogeny of Favosites, Syringopora, and other tabulate corals, all of which are shown to go through an Aulopora stage of growth.

Echinodermata.-The only crinoid of which the ontogeny is known is Antedon, which has been shown by Sir Wyville Thomson (1865) to go through successively stages corresponding to the Ichthyocrinoidea of the Paleozoic, and Pentacrimus of the Mesozoic, before it becomes free swimming and takes on the characters of Antedon. 
Dr. R. T. Jackson (I895) has been able to prove even in the Paleozoic sea-urchins the possibility of correlating growth stages with phylogeny, in spite of the great difficulties due to resorption of plates, and change of form.

Brachiopoda.-According to Beecher (I89I, I892) all brachiopods go through a primitive protegulum stage, correlative with the supposed ancestor of the class, although Paterina, which was formerly supposed to be this radicle, has been shown to be much more highly specialized than the protegulum stage. The later stages of growth of this class are capable of even more remarkable correlation, as has been shown by Beecher ( $1893^{a}$ ) in a number of papers, where every stage of growth is distinctly homologous with well known pre-existing genera; and these same successive genera show a gradual transition in the adults.

Even among the Paleozoic spire-bearers (Helicopegmata), this holds good, for Beecher, and Schuchert (I893) have demonstrated that the early stages of this group are homologous with the terebratuloids (Ancylobrachia), and more especially with the Paleozoic genus Centronella, the most primitive of the loop-bearing brachiopods.

Mollusca.-Jackson's correlations of the stages of growth of pelecypods (I890) with their race history have already become classic; according to these, every pelecypod begins its bivalve state with a nuculoid stage, homologous with the primitive radicle of the group. Every Pecten goes through stages successively correlative with a nuculoid, Rhombopteria, Pterinopecten and Aviculopecten, before it reaches maturity, each stage appearing in the order of the ancestral genus. Even the greatly modified oyster shows its kinship with this group by its nuculoid and Rhombopteria stages.

The researches of Branco have made it clear that each group of cephalopods has its typical phylembryo, in a general way correlative with the radicle of the group, and that the later stages may be compared very accurately with ancestral families and genera. The way for this was opened by Hyatt's memoirs on the ontogeny of the ammonites, in which it was shown that in each perfect adult ammonite shell the complete individual ontogeny is recorded. By 
using this same method Karpinsky ( 1889 ) has been able to correlate the ontogeny of Medlicottia and Pronorites with successive ancestral forms, from Anarcestes, Ibergiceras, Paraprolecanites, up to the adult stage.

By the ontogenic method Buckman has been able to get at a sound basis of classification of the Jurassic ammonites, and to correlate the growth stages of many of these with their race history. Although his conclusions as to the systematic position of many of these genera do not agree with the ideas commonly accepted concerning them, it must not be forgotten that these conclusions are based, not merely on ontogenic study alone, but also on the gradual transitions of a series of adults. This is the strongest confirmation that any phylogenic research could ever have.

Crustacea.-Among the most convincing morphogenic researches are Beecher's studies (I895) in the ontogeny of the trilobites, all of which are shown to go through a phylembryonic protaspis stage, correlative with the primitive crustacean, and similar to the protonauplius of the less specialized living crustaceans. Here, too, it was demonstrated that the larval and adolescent stages of Devonian, Silurian, and even Cambrian trilobites may be correlated with the adults of pre-existing genera, giving the basis of a natural, or biogenetic, classification of this extinct group.

Many more cases might be added to those cited here, but surely no additional evidence is needed, for all this points in the same direction, whether gathered by believers in or by opponents of the theory of evolution. To this latter class belongs the evidence brought forward by Barrande ( $185^{2}$ ) in the ontogeny of trilobites, and by Agassiz in the law of recapitulation or acceleration of development. Each of these naturalists used unhesitatingly the method that in the hands of Hyatt and his followers has been so fruitful of results.

\section{Affinities of Placenticeras and Hoplites.}

The genus Placenticeras was established by F. B. Meek ( 876 ) to include large, discoidal, compressed shells, with narrow umbilicus, narrow, flattened abdomen, and rows of 
knots forming a pair of marginal keels on the abdomen; shell with obscure knots or ribs, but with fine sigmoid lines of growth; septa divided into a large number of lateral lobes and saddles, increasing in size up to the third, and decreasing from that toward the umbilicus. The type of the genus was Placenticeras placenta Dekay, of the Fort Pierre group, Upper Cretaceous. Along with the type species Meek included in this group also $P$. andoorense Stoliczka, $P$. guadaloupe Roemer, and $P$. orbignyanum Geinitz, all from the Cretaceous. Meek did not attempt to place Placenticeras in any of the so-called families of ammonites, but by almost universal consent paleontologists have grouped it with the Amaltheidæ (Zittel, I885, p. 452; I895, p. 407; Steinmann, I89o, p. 4I6), along with the so-called "Ceratites" of the Cretaceous, on account of a certain resemblance to the Jurassic forms with beaded abdominal keels. This, however, was before the days when paleontologists looked upon the development of ammonites as the key to their systematic position, and taxonomy made little pretense of being biogenetic.

The first dissenting voice was raised by $H$. Douvillé, in a paper "Classification des Cératites de la Craie" (I890), where the opinion was expressed that Placenticeras and Sphenodiscus both developed out of the group of HoplitesSonneratia. F. Bernard (1895, p. 676) has accepted this view, placing the genus under the Stephanoceratidæ. Unpublished researches of the writer show, however, that Someratia and Desmoceras are much more closely allied to Stephanoceras than is Hoplites, from which group Placenticeras originated. Hoplites is considered by the writer, not as originating from the Stephanoceratidæ, but as having a common origin with that family in the $Æ g o c e r a t i d æ$.

The species from the Lower Cretaceous commonly assigned to Placenticeras mostly belong to Oppelia, to Sphenodiscus, and to other genera. Not every keeled, discoidal ammonite can be placed here, for it is well known that among the ammonites mere resemblance is not proof of near kinship. Sarasin (1893) has shown that Ammonites 
nisus d'Orb. belongs to Oppelia, and that there are several series of these plate-shaped ammonites, commonly ascribed to the Amaltheidæ, but in reality derived from wholly different groups.

The true species of Placenticeras, that is of the type of $P$. placenta, are descendants of Hoplites, and thus have no kinship with the Amaltheidæ; this is the opinion of H. Douvillé, and it has been fully confirmed by an ontogenic study of two species. These species had been under investigation by the writer for a long time before their real affinities were found out; the largest specimens obtained were between 20 and 30 millimetres in diameter, and were naturally supposed to be adults, for on the last coil there was no further progressive development. One species was remarkably like Hoplites dufrenoyi, and the other like $H$. splendens, both of the Gault; thus they were assigned to Hoplites, although the premonition of Placenticeras was shown in the provisional name, "H. placenticeratoides," given by the writer, and in the unpublished description, in which it was said that this species was tending decidedly toward becoming a Placenticeras, although it had not yet quite developed beyond the limits of Hoplites. After this was written, although luckily not published, the writer obtained a number of larger specimens of both species, up to $\mathrm{r} 7 \mathrm{O}$ millimetres in diameter, showing a perfect and gradual transition between the two genera.

The earliest known species of Placenticeras occur along with Sphenodiscus in the zone of Mortoniceras rostratum (=Schloenbachia inflata), in the Albian stage, upper Gault, top of the Lower Cretaceous. Thus the genus must have developed out of Hoplites in the upper part of the Lower Cretaceous. Now since the origin and affinities of Hoplites are pretty well known, a discussion of this genus becomes of prime importance in an investigation of the derivation and systematic position of Placenticeras.

The genus Hoplites was established by Neumayr (I875) to include forms with rather compressed flattened sides, high whorls, moderately narrow umbilici, sinuous lateral ribs with umbilical and marginal knots or spines, and usually 
with a furrow interrupting these ribs on the abdomen, often forming a pair of shoulder keels. The septum is finely and deeply divided; in addition to the first and second lateral lobes there are one or more auxiliary lobes, and the two lateral saddles are deeply divided by secondary lobes.

This genus, which Neumayr supposed to have originated from Perisphinctes, included many species that have since been placed in other genera, in some cases even in other families, but after the segregation from it of Sonneratia Bayle, Stoliczkaia Neumayr, Pulchellia Uhlig, there is still left a large number of species, showing great variation in form and other characters, which may, after all, not belong to a monophyletic genus. Zittel (I885, p. $475 ;$ I 895, p. 428 ) first classed Hoplites with the Stephanoceratidx; then in a later work, with the Cosmoceratidæ, along with Cosmoceras Waagen, Parkinsonia Bayle, Sonneratia Bayle, and Acanthoceras Neumayr, as a side branch from the Stephanoceratidæ. Zittel is inclined to the belief that Cosmoceras is the direct ancestor of Hoplites, an opinion which seems to be the more correct, for the two species of Placenticeras, of which the ontogeny is described in this paper, show a decided Cosmoceras stage in the adolescent period just before the Hoplites stage, and one of them retains some of these characters until maturity. In each case this stage begins by a sudden stopping of the perisphinctoid ribs on the abdomen, the formation of strong knots on the angular abdominal shoulders, and a sharper forward bending of the lateral ribs, which fork near the shoulders, forming the beginning of a second row of knots. At this stage one can see a resemblance, not to the exaggerated species of Cosmoceras, such as $C$. ornatum, $C$. jason, or $C$. elizabetha, but rather to some simpler form; it is not possible to refer to any particular species as the ancestral form, nor is it likely that any one species was the only one that developed the style of rough ornamentation that is called Hoplites.

F. Bernard ( 1895 , p. 673) agrees substantially with Zittel as to the systematic position of the genus, as do also most other writers on the subject; Steinmann (I89o, p. 445) groups it 
in the Egoceratidæ, subfamily Perisphinctinæ, division (b) Tuberculati, along with Acanthoceras and Holcodiscus. All these writers connect the genus with Psiloceras as the radicle from which the entire perisphinctoid stock sprang, although the opinion is based, not on ontogenic study, but purely on the geologic succession of types, a satisfactory method only where the paleontologic record is very complete.

In a later paper Sarasin (I897) concludes, as a result of ontogenic study, that Hoplites is not a member of the highly specialized Stephanoceratidæ, but comes from the more primitive perisphinctoids along with Desmoceras. Most writers agree that the perisphinctoids come from the Egoceratidæ, that they, in turn, are derived from Psiloceras, and that this genus branched off from the Phylloceratidæ. E. Haug (1894) expresses the opinion that not only the Egoceratidæ, but also the Amaltheidæ, the Arietidæ, and most of the other Jurassic stocks were derived from the Phylloceratidæ, because their septa are triænidian in early youth, and megaphyllian in the development of the principle saddles. This seems to be nearer the mark, although the descent must be from some of the earlier unspecialized forms of the Phylloceratidæ, such as possibly Monophyllites, although certainly not from any known species of that genus; at any rate, none of these genera show a Psiloceras stage in their ontogeny. S. S. Buckman (r898, p. 445), contrary to the general opinion, says that Psiloceras is not the ancestor of the Arietidæ nor the Agoceratidæ, but is, itself, a degenerate form.

The immediate ancestors of the Fgoceratidæ may be sought among the Polymorphidæ, a group established by E. Haug ( 1887 ) to include a number of the more primitive ammonites of the Lias. Agassizceras, the principal genus of the group, is considered by Hyatt ( 1889 ) to be the immediate ancestor of the agassizceran branch of the Arietidæ, and the direct descendant of Psiloceras. Neumayr (1878) segregated a number of the simpler species of this group under the name of Cymbites, characterized by rather globose form, very slightly ammonitic septa, and absence of 
ventral keel. Hyatt (I889) says Cymbites is probably only the young of Agassizceras, while Haug considers the characters upon which Neumayr based the genus not to be sufficiently constant to warrant the separation, although he regards the problematic species as adult forms. However this may be, we know that the young of the more specialized Polymorphidæ are like Cymbites, and whether the forms described by Neumayr were adults or not, there must have been such a genus as ancestor of the group, and not only of this small section, but also of the Egoceratidæ as well; so it will be well to retain Cymbites, although Buckman leaves this genus out of the Polymorphidæ, which he does not consider the primitive family.

Another form that may possibly be in the genetic series of the Egoceratidæ, and thus of Placenticeras, is the genus Diaphorites Fucini (I896, $a$ and $b$, p. 232, Pl. XXV, figs. I-I5), which, although small, is surely made up of adult forms. This genus greatly resembles Cymbites, and is thought by Fucini to be genetically connected with the Phylloceratidæ; the youthful stages of Diaphorites vetulonius Fucini, as described and figured by that author, are remarkably like the young of Placenticeras pacificum, sp. nov., figs. I 3 and I4 of Fucini's paper, reproducing exactly the glyphioceran stage, and fig. I 2 is like the Nannites stage of Placenticeras. The early adult septa of Diaphorites, copied on plate XXVIII, fig. 7, after Fucini, are almost exactly like the early adolescent septa of Placenticeras, and the parallel is also quite exact as to form and sculpture. As only one species of the genus is known as yet, and that only in Italy, it would be premature to single this out as the connecting link between the perisphinctoid group, and the phylloceran stock; the most we can say is that this connecting link must have been some such genus.

Fucini (1896, $a$ p. I 24 , and $b$ p. 236, Pl. XXV, figs. I62I) has described another genus, Pimelites, that might possibly be the radicle of the ægoceran stock; it is very like Diaphorites, differing only in some unimportant characters, and being, in Fucini's opinion, intimately related to the 
Phylloceratidæ, and regarded as a possible ancestor of Coloceras, Spheroceras, and Stephanoceras. Until the ontogeny of the genus is worked out, opinions on its phylogeny can not be much more than speculations.

The more remote derivation of the $Æ$ goceratidæ is still more uncertain; Hyatt and nearly all other paleontologists regard Psiloceras as the radicle of the group, while many derive Psiloceras from the Phylloceratidæ, the development and phylogeny of which group have been very fully discussed by the writer in a recent paper (1898). In his opinion the ammonite radicle of this group is to be sought in Nannites, or in some Permian or Triassic genus of that transitional character. No attempt was made to trace the genealogy back into the goniatites, further than to indicate the probability that the remote radicle would be found among the Prolecanitidæ. The ontogeny of Nannites is still wholly unknown, but the writer has recently worked out the development of an undescribed genus, associated with, and evidently very closely related to Nannites, with larval and adolescent stages showing unmistakable glyphioceran affinities. F. Bernard ( 1895, p. 656) derives the Phylloceratidæ from Popanoceras, which is most improbable, in view of the evident derivation of that genus from the primitive Arcestidæ. E. Haug (x898, p. 45) traces the Phylloceratidæ through Monophyllites back to Nomismoceras and Gephyroceras of the phylum Gephyroceratidæ; although, as shown by the writer, the young stages of both Phylloceras and Lytoceras show an unmistakable resemblance to Glyphioceras; the ontogeny of Nomismoceras is unknown, so any attempt at present to trace its origin must be largely speculative; it may, however, have come from Glyphioceras.

Whatever the goniatite radicle of this group may have been, the secondary radicle of Hoplites, Desmoceras, Aigoceras, Perisphinctes, and Coloceras was the same for all. The young stages of Hoplites, as figured by Branco (I879, Pl. XIII, fig. 2, $a-m)$, resemble the young of Perisphinctes (Branco, I879, Pl. XIII, figs, I, $a-l$ ), while both resemble the larval and early adolescent stages of Coloceras, as illustrated on Plate XII of Branco's memoir, and of Desmoceras 
(Puzosia), on Plate XI, fig. 5, $a-k$. On Plate XIII, fig. 5, $a-n$, Branco has figured the early stages of Cymbites, which show all the essential characters observed in the larvæ of the other genera mentioned, although less accelerated, and necessarily more primitive.

The systematic position of Hoplites, according to the investigations of the writer, and of Sarasin (with whom the writer substantially agrees), is not with the Stephanoceratidæ, but with the Perisphinctinæ. Desmoceras, on the other hand, undoubtedly belongs to the Stephanoceratidæ, along with Sonneratia, for adolescent stages of both genera resemble perfectly Stephanoceras ${ }^{1}$ and Holcostephanus, and these, in turn, sprang from Coloceras. The ægoceran ancestor of Coloceras and of the perisphinctoid group is the same, and can be traced back to a Cymbites-like form, and this must have originated in a genus with the essential char acters of Nannites, with the possible intermedium of some primitive unknown member of the Phylloceratidæ. The immediate ancestor of Hoplites is not to be sought in a perfected Cosmoceras, nor did this genus spring from any highly specialized Perisphinctes, which, according to Buckman, is a degenerate group of the Stephanoceratidæ; nor was any fully differentiated ægoceran form the parent of this perisphinctoid ancestor. We must rather seek, in each case, the radicle in the primitive, unspecialized beginnings of each group. And if all these genera come from a phylloceran stock, they certainly do not come from Psiloceras, Phylloceras, nor Lytoceras, but from some primitive member of the Phylloceratidæ, as yet unknown, or at least not recognized as belonging to that group. At any rate, the stage between that resembling Nannites, and that suggesting Cymbites, is too short, and too little differentiated in any species of Hoplites yet investigated for a probable reference to Monophyllites.

\footnotetext{
1 The writer has recently worked out a remarkably perfect series of Sonneratia stantoni Anderson MS., Desmoceras haydeni Gabb, D. breweri Gabb, and D. hoffmanni Gabb, on which series the above statements are based.
} 
As to the goniatite radicle of Hoplites and of the other perisphinctoids, the writer's investigations point to some glyphioceran form, possibly Glyphioceras itself. Now E. Haug (I898, pp. 39, 46, 73) claims that Hyatt's family, Glyphioceratidæ, is nothing but a group of morphological equivalents from three distinct stocks or phyla, the Glyphioceratidæ proper, the Gephyroceratidæ, and the Agoniatitidæ; a number of species grouped in this latter phylum are classed together under the new name Pronannites, as supposed ancestors of Nannites. Just this very group of glyphioceran forms most nearly resembles the goniatite stage of Hoplites. Haug is, then, in essential agreement with the writer, although he calls these by other names. Now since this classification of the goniatites, although certainly the best proposed up to this time, is too arbitrary, based too little on what we know, and too much on what may be so, the writer prefers for the present to call the goniatite stage of Hoplites glyphioceran, freely admitting that it may eventually be referred to Pronanites, or to some other genus at present insufficiently known. And should any of these stages be correlated with Nomismoceras, this genus should still, according to E. Holzapfel (I899), be referred not to the Gephyroceratidæ, but to the Glyphioceratidæ, the morphogeny of which group has already been described by the writer (Smith 1897). Nomismoceras is probably a derivative of Glyphioceras, for some species of Lytoceras, after passing through a glyphioceran stage, show what might be called a nomismoceran stage. 


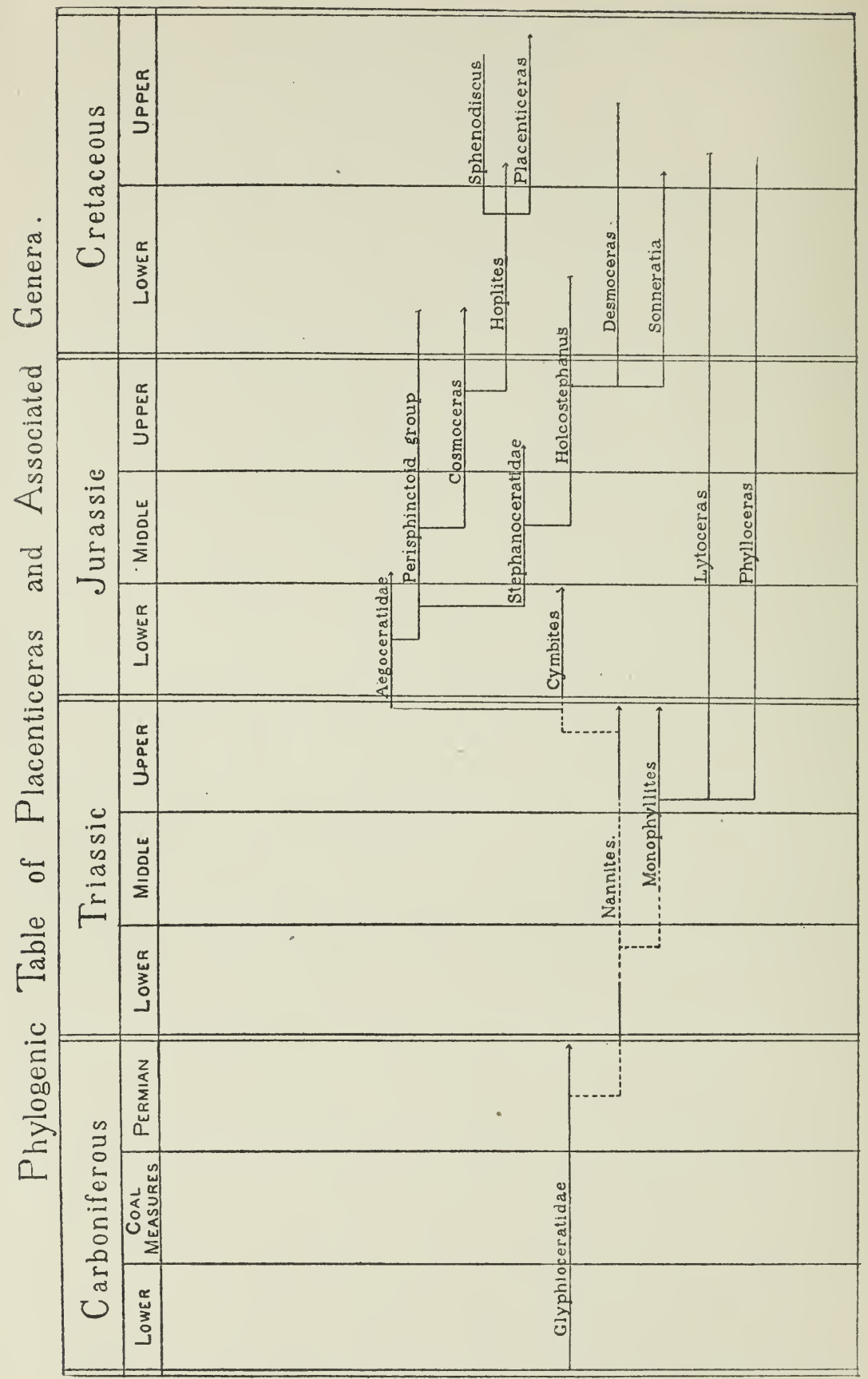




\section{Placenticeras californicum Anderson (MS.).}

Plate XXV, Figs. i-8; Plate XXVIII, Fig. 6.

Placenticeras californicum is most nearly related to $P$. guadaloupce (Stoliczka, not Roemer), as described and figured by F. Stoliczka (186r), although it is more compressed laterally, and somewhat rougher shelled than the Indian species. The largest specimen found had the following dimensions:

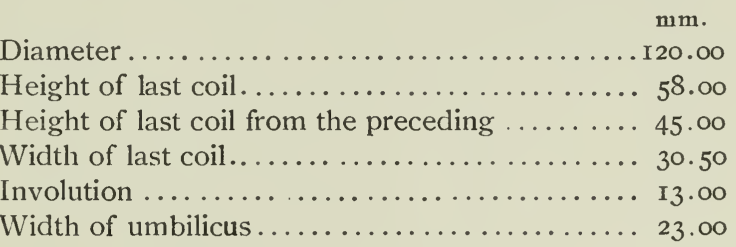

This specimen had about six revolutions, showed the body chamber to be about two-thirds of the last whorl, and since there was no further progressive development, seems to have been fully mature. The abdomen is narrow, flattened, with low central keel, and with marginal keels made up of a row of elongated knots. The sides are ornamented with rough sigmoidal ribs, branching out from coarse umbilical knots, and forming the knots on the abdominal shoulder keels.

Another specimen of five and a half revolutions was exactly like the larger one, and gave the following dimensions :-

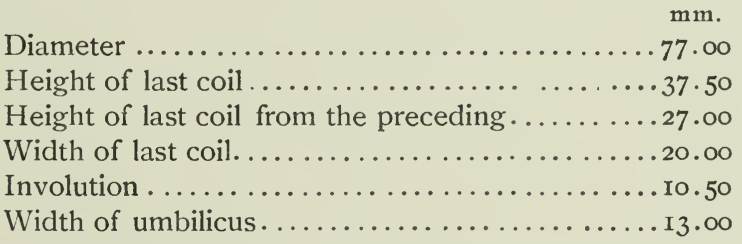

Horizon and Locality.-A single specimen of this species was found by Dr. L. G. Yates on the ranch of Mrs. Isabella Jordan, on the Arroyo del Vallé, Alameda county, California, about eight miles southeast of Livermore. Associated with it were found the following species: Baculites chicoënsis Trask; Desmoceras hoffmanni Gabb; D. ? selwynianum Whiteaves; Hoplites remondi Gabb; Holcostephanus? suciaënsis Meek; Lytoceras alamedense Smith; Lytoceras batesi Trask; L. (Tetragonites) cf. cola Stoliczka; L. cf. timotheanum Mayor; Placenticeras pacificum, sp. nov., Smith; Phylloceras onoënse Stanton; P. ramosum Meek; Cinulia obliqua Gabb; Inoceramus cf. vancouverensis Shumard; 
Trigonia evansana Meek; Pectunculus veatchi Gabb, and other species not identified, or not characteristic. This fauna is rather contradictory and puzzling, so that in a former paper (Smith, I898, p. I38) the writer expressed the opinion that either the fossils from that locality, but from different beds, had not been differentiated in collecting, or that the strata were transitional from Horsetown to Chico. A visit in person to the locality, in the spring of I899, enabled the writer to find out definitely that there was only one fossiliferous bed; and the identification of two species of Placenticeras, the young stages of which were formerly supposed by the writer to be Hoplites, place the Chico age, Cenomanian, of these beds almost beyond doubt. A still more certain determination of the age of this species is given by its occurrence, along with $P$. pacificum and a large number of typical Chico species, in the Chico beds onehalf mile west of Henley, near Hornbrook, Siskiyou county, California, where it was discovered by Mr. Frank M. Anderson, to whose liberality the writer owes the use of all specimens of $P$. californicum from that locality figured in this paper. ${ }^{1}$

During the summer of 1899 Dr. Stephen Bowers, of Los Angeles, collected a number of Chico fossils in the San Fernando mountains, Los Angeles county; these were sent to the writer for inspection, and several specimens of $P$. californicum were found among them. From its wide range in northern, central, and southern California, always in the same horizon, it is fair to assume that $P$. californicum is characteristic of the lower Chico, or Cenomanian portion of the formation.

Poorly preserved young specimens of this species have a certain resemblance to Schloenbachia chicoënsis, and have been occasionally mistaken for it; but the young stages of the two genera are so entirely different that a mistake is hardly possible if one examines the inner coils.

\footnotetext{
${ }^{1}$ In the Proceedings of the California Academy of Sciences, 3d Series, Mr. Anderson will describe this fauna in his monograph on the Cretaceous, and with his permission the writer uses his manuscript name "Placenticeras californicum Anderson."
} 


\section{Larval and Adolescent Stages.}

The earliest stages of Placenticeras californicum could not be observed on the specimens at hand. The smallest specimen obtained, figured on $\mathrm{Pl}$. XXV, figs. I and 2, was in the perisphinctoid stage, and very like the corresponding stage of Placenticeras pacificum, except that the shell is a little rougher, and somewhat more evolute than on that species; it consisted of two and three-eighths coils, and had the following dimensions:-

Height of last coil....................... 44

Height of last coil from the preceding ........... II

Width of last coil ...................... 33

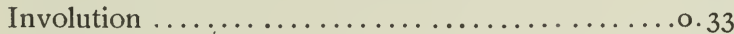

Width of umbilicus .....................16

At about two and a quarter coils the constrictions cease, the ribs end in knots on the abdominal shoulders, and the cosmoceran stage begins at diameter of about four millimetres, just as in $P$. pacificum, but the sculpture is rougher, and the shell more robust. At about three coils and diameter of eight millimetres the sculpture and shape of the shell resemble strongly Hoplites tuberculatus Sowerby, of the Gault; this specimen, figured on Pl. XXV, fig. 3, gave the following dimensions:-

Diameter ..............................

Height of last coil..................... ro

Height of last coil from the preceding .........2.80

Width of last coil............................. 30

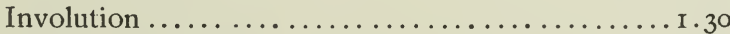

Width of umbilicus .................... 80

At three and five-eighths coils, diameter $\mathrm{I} 4 \mathrm{~mm}$., the resemblance to the group of Hoplites interruptus has become so striking that the young shell might well be taken for an adult of that group, were it not for the fact that this entire group of Hoplites was either extinct at this time, or at least had changed entirely into other genera. This specimen is figured on $\mathrm{Pl}$. XXV, figs. 4 and 5 , to illustrate the most typical Hoplites stage of growth of the species, and to show the striking difference between $P$. californicum and $P$. pacificum at this stage. Both correspond to Hoplites, and 
both to the group of $H$. interruptus, but the late adolescent stage of $P$. pacificum corresponds closely to $H$. splendens, while $P$. californicum corresponds to the rougher and more evolute species, and retains many cosmoceran characters lacking in the other form.

As the adolescent period advances the resemblance to Hoplites dufrenoyi d'Orbigny, of the Gault of Europe, becomes marked, although $P$. californicum differs from the European species in having the ribs finer, more numerous, more sharply bent on the sides, and in having the rows of knots on the abdominal shoulder keels closer together, and weaker. There is also a rather faint second row of knots high up on the sides, where the ribs fork at the sharp forward bend; this is a cosmoceran character lacking on $H$. dufrenoyi. The ribs start out in pairs from a knot on the umbilicus, and between each pair there is usually a single rib intercalated. The rows of knots on the umbilicus, on the sides, and on the abdominal shoulders, are stronger at diameter of fifteen millimetres than at maturity, showing this to have been characteristic of the immediate ancestor of the genus. The relative measurements agree exactly with $H$. dufrenoyi, except that on the Californian species the whorl is broader, and the cross-section polygonal.

The adolescent stage of $P$. californicum, Pl. XXV, figs. 6 and 7 , at about four coils, gave the following dimensions :-

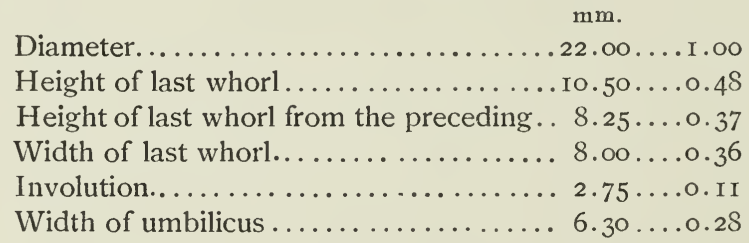

Compare with these the almost identical measurements of $H$. dufrenoyi, at the same stage of growth:-

$\mathrm{mm}$.

Diameter......................2I.50... I. oo

Height of last whorl............... 10.00...0.47

Height of last whorl from the preceding $\cdot 7 \cdot 50 \ldots 0.35$

Width of last whorl .............. $6.50 \ldots .30$

Involution . ................. $2.75 \ldots \ldots$

Width of umbilicus ..............6.00...0.28 
On the fifth whorl the likeness to Hoplites becomes less, and the characters of Placenticeras more strongly accentuated; the central abdominal keel stands up almost as high as those on the shoulders, while the sigmoidal ribs are no longer so sharp as in the earlier adolescent stages. This may be considered as the transition to maturity, although the Hoplites characters do not disappear at once, nor do the Placenticeras characters appear all at the same time; some, in fact, show even at the beginning of the adolescent stage. A specimen illustrating the transition is figured on Pl. XXV, fig. 8; it consists of four and a half coils, and gave the following dimensions:-

$\mathbf{m m}$.

Diameter............................... 54

Height of last coil.................... 80

Height of last coil from the preceding ......... I3.00

Width of last coil...................... 9.50

Involution $\ldots \ldots \ldots \ldots \ldots \ldots \ldots \ldots \ldots \ldots \ldots \ldots \ldots \ldots \ldots+5 \cdot 00$

Width of umbilicus..................... 5.00

$P$. californicum might easily be confused with $P$. guadaloupa Stoliczka (186I) (not Roemer), of the Trichinopoly group, Upper Cretaceous ${ }^{1}$, but differs from it in being more compressed laterally, in having rougher sculpture, and in lacking the heavy nodes on the sides below the abdominal shoulders. The two species may be identical, but until we know the limits of variation of them, it would be unsafe to class them together.

\section{Placenticeras pacificum, sp. nov.}

Plate XXIV, Figs. I-2I; Plate XXV, Figs. 9-II; Plate XXVi; Plate XXVII, Figs. I-I3; Plate XXVIII, Figs. I-5.

Placenticeras pacificum is large, discoidal, involute, and laterally compressed, having the typical plate shape of the genus. At maturity the whorl embraces somewhat more than one-half of the preceding; the breadth of the whorl is one-fifth of the diameter, the height of the whorl is three-sevenths, and the width of the umbilicus one-fifth. The body-chamber is about twothirds of a revolution in length. The abdomen is narrow, flattened, slightly concave, bounded by a row of elongated knots forming rough keels. Up to diameter of about one hundred millimetres, five and a half coils, the shoulder

\footnotetext{
1 Stoliczka's species is probably not identical with Roemer's $P$.guadaloupa, from the Lower Cretaceous of Texas, zone of Mortoniceras rostratum.
} 
keels are rather finely notched by the ends of the lateral ribs; at this stage the coarse elongated knots of Placenticeras appear, and deep undulations cross the abdomen; a central keel, which has persisted up to this stage, becomes obsolete. The sides are ornamented with rather coarse sigmoidal ribs, bundling on umbilical knots; these show on the cast even more strongly than on the shell. The outer shell has numerous sigmoidal striæ covering the ribs and the interspaces. The umbilicus is moderately narrow, and the shoulders angular, becoming more so as age advances. At five and two-thirds coils the umbilicus is one-sixth of the diameter, while at six and one-third coils it widens out to one-fifth, this change probably indicating old age, for the slackening of the increase of height of the body-chamber shows a decrease in growth force.

The septa consist of an abdominal lobe with a pair of long branches, and seven lateral lobes, all finely digitate, and rather narrow. The saddles are broader and deeply divided by narrow secondary lobes.

Douvillé (1890, p. 288) says that in Placenticeras the first, second, and third lateral lobes are probably formed out of divisions of a primary lobe, and that the fourth is really the second primary. But the development of this species shows that the first lateral lobe is developed out of a division of the primary lateral saddle, and that the second, third and fourth lobes are developed out of notches in the primitive first lateral lobe. There are also three auxiliary lobes on the sides, and one on the umbilical shoulders, growing simpler as the umbilicus is approached. This is a common and well known fact, ascribed by Jackson (I899) to the principle of localization of stages of growth, by which more primitive characters are preserved in the dorsal and umbilical portion of the shell. At early maturity these lobes are arranged in a wide backward-pointing curve, but in later growth this curve is not nearly so pronounced. The development of the septa, as shown in the adolescent stages, makes it clear that the three chief lateral lobes are merely modifications out of the three points of the triænidian primitive lateral lobe. This explains the arrangement in a curve, and also the straightening out of this curve as full maturity is approached. This suggests a probable explanation for the large number of lobes found in many ammonites, such as Placenticeras and Sphenodiscus, although it is not yet known that the development of the latter genus takes place in this way. The arrangement of the lobes in 
Placenticeras guadaloupa Roemer (Pl. XXVIII, fig. 8) suggests this origin for part of them. It is commonly accepted that in the ammonites new elements in the septa develop on the dorsal side near the umbilicus, and appear on the outside only in later growth; here in the development of Placenticeras this is decidedly not the case, for the three principal lobes are developed out of one that was on the outside from the very beginning.

Placenticeras pacificum is most nearly akin to $P$. californicum, with which it agrees in the width of the umbilicus, but from which it differs in the more compressed whorl, more numerous, finer ribs, and the smaller size of the knots on the umbilicus. In $P$. pacificum the breadth of the last whorl is one-fifth of the diameter, and in $P$. californicum it is one-fourth, but in the young stages the relative measurements of the two species are very much the same, although there is no danger of confusing them above the diameter of four millimetres. $P$. pacificum might also be compared with $P$. guadaloupa Stoliczka (I86I) (not Roemer), but the Indian species is even thicker than $P$. californicum, and has a row of coarse knots on the umbilical shoulders, and another near the abdominal shoulders, which would distinguish it from either Californian shell. Also, the ribs on the Indian species do not show that strong sigmoidal bend seen on the others.

Horizon and Locality.-Placenticeras pacificum was first found by Dr. L. G. Yates on the Arroyo del Vallé, ranch of Mrs. Isabella Jordan, Alameda county, California, about eight miles southeast of Livermore. Associated with it were found the following species: Baculites chicoënsis Trask; Desmoceras hoffmanni Gabb; D.? selwynianum Whiteaves; Hoplites remondi Gabb; Holcostephanus? suciansis Meek; Lytoceras alamedense Smith; Lytoceras batesi Trask; L. cf. cola Stoliczka; L. cf. timotheanum Mayor; Placenticeras californicum Anderson (MS.); Phylloceras onoënse Stanton; $P$. ramosum Meek; Cinulia obliqua Gabb; Inoceramus cf. vancouverensis Shumard; Pectunculus veatchi Gabb; Trigonia evansana Meek; Nucula truncata Gabb, and other 
species not especially characteristic. This fauna almost undoubtedly indicates the lower part of the Chico formation Cenomanian, Upper Cretaceous.

$P$. pacificum was afterwards found by Mr. F. M. Anderson one-half mile west of Henley, near Hornbrook, Siskiyou county, California, associated with $P$. californicum, Pachydiscus newberryanus Meek, Phylloceras ramosum Meek, Hoplites cf. remondi Gabb, Chione varians Gabb, Mactra ashburneri Gabb, Cinulia obliqua Gabb, Cylichna costata Gabb, and a number of other characteristic Chico species; from this locality came the type of the species, figured on Pl. XXVI. Mr. F. Rolfe has recently found this species in the lower Chico beds of the canyon of Silverado creek, near the old coal mine, about two miles east of the mouth of the canyon, where Silverado empties into Santiago creek.

Placenticeras pacificum, since it occurs in the same horizon in northern, middle and southern California, may be taken as characteristic of the lower Chico; so the reference of the beds to the Horsetown, made by the writer (Smith, I898) in a former paper, will have to be revised, for a careful study has shown the accompanying faunas at all three localities to be characteristic of the Chico, and not of the Horsetown.

\section{Larval Stages. ${ }^{1}$}

Phylembryonic Stage.-The young Placenticeras was undoubtedly shelled before it was hatched, although it was not possible, on the specimens under investigation, to find out certainly the limits of the primitive embryonic body-chamber; but this seems to have coincided approximately with the limits of the protoconch, although it may have included somewhat more of the spiral coil. Branco (r879, p. 24), on the other hand, is of the opinion that the embryonic shell could not have taken up the entire protoconch, but must have been homologous with the primitive cap-shaped shell of the

\footnotetext{
${ }^{1}$ In the nomenclature of stages of growth the writer has followed Hyatt's "Phylogeny of an Acquired Characteristic."
} 
gastropods, and only in later growth was the spiral formed. It has, however, been shown by Dr. Amos Brown (I892) that in Baculites the limits of the embryo chamber lie between the first and second septa. This has also been observed by the writer on the young of Baculites chicoënsis, and on Lytoceras alamedense.

The protoconch of Placenticeras pacificum (Pl. XXIV, figs. I-3) has diameter $0.54 \mathrm{~mm}$., and width $0.75 \mathrm{~mm}$.; it is smooth, oval, and covered by the primitive nacreous shell, which extends to the end of the first coil. This protoconch is very similar in all the later ammonites, and is probably an adaptive form, due to life in the egg, and does not represent any ancient ancestral genus, for none of the early cephalopods were shaped like this. It is, then, the typical embryo of the ammonoids, and yet can hardly be said to be correlative with any group of cephalopods.

Ananepionic.-With the formation of the first septum the young ammonite has taken its place among the chambered cephalopods, and has become, for the time being, a nautiloid, although it is not possible, from the exceedingly simple nature of the shell, to correlate it with any especial genus. Nor, indeed, is it strictly homologous with any ancient nautilian form, for the larval ammonite even in its first stages possesses several elements unknown in that group. The first septum, which separates the larval bodychamber from the embryonic shell, is nautilian in character, but the siphuncle begins inside the protoconch with a siphonal knob, or cæcum, and the protoconch itself is calcareous. These are two characters that the nautiloids, even to this day, have never yet acquired. It would, then, be impossible to correlate the ananepionic stage with any ancestral genus, since we have in this stage ammonoid characters pushed back by unequal acceleration, until they occur contemporaneously with more remote ancestral characters. This stage and these characters can not correctly be called adaptive, for they are undoubtedly hereditary, although not inherited at equal rates. 
The ananepionic septum (Pl. XXVII, fig. I) consists of a narrow, undivided, abdominal saddle, and a short lateral saddle; the internal portion of the septum is gently curved, and gives little indication of the lobes and saddles that appear on the second chamber-wall. The only part of the shell that can with certainty be assigned to the ananepionic period of growth is that lying between the first and second septa, but that is probably not all of this second living chamber. The outer nacreous shell is smooth and devoid of all ornament until the end of the first coil, hence it seems likely that the ananepionic body-chamber extended throughout this coil, the end of which is marked by a distinct constriction, and beginning of sculpture, as seen on Pl. XXIV, figs. 3-9. While this portion of the shell became chambered in later larval stages, it was a spiral unchambered coil during the first free stage of the animal. This is true not only of this species of Placenticeras, but also of the early larval stages of every ammonite yet seen by the writer, embracing typical genera from the Carboniferous, Trias, Jura, and Cretaceous, retrogressive and progressive forms alike.

Metanepionic.-Following the usage of Hyatt, the middle larval stage is considered to have begun when the shell has assumed ammonoid characters; this happens with the formation of the second septum, and continues as long as only simple goniatite characters are seen. In the older ammonoids the second septum always has an undivided ventral lobe distinctive of the Nautilinidæ and their immediate descendants; but in the later and more specialized ammonites the second septum already has the ventral lobe divided by a siphonal saddle, so that the record of the Nautilinidæe is lost from the shell. The metanepionic stage is shown on $\mathrm{Pl}$. XXIV, figs. 3-7, and its septa on Pl. XXVII, fig. 2. The divided ventral lobe, the lateral lobe and that on the umbilical shoulder, along with the broad low whorl and smooth shell, all remind one strongly of Glyphioceras, a genus diagnostic of the Carboniferous; because of this resemblance, and because some member of the Glyphioceratidæ may probably have 
been the ancestor of Hoplites, this stage is called glyphioceran, although Pronannites, or several other genera excluded from this family by some writers, may have been the parent group. In all probability this stage is prosiphonate, although the siphonal collars could not be seen on any specimen, for the higher members of the Glyphioceratidæ become prosiphonate with advancing age, and many of the Cretaceous ammonites investigated become prosiphonate almost as soon as they reach the goniatite stage of development.

At about one-quarter of the first revolution from the protoconch, and at the fourth chamber-wall, a second internal lateral lobe is added, something that no member of the Glyphioceratidæ is known to have possessed ${ }^{1}$ this stage is distinctly goniatitic, and yet not comparable to any known genus, but is probably the result of unequal acceleration of the septation, introducing elements that belonged to later genera. This is shown on Pl. XXVII, fig. 2, and illustrates the multiplication of the lobes by the division of those inside the umbilicus, and gradual pushing of these towards the ventral portion of the shell.

Paranepionic.-At about five-eighths of a coil the new internal lobe reaches the umbilical border, and the shell then has two principal lateral lobes and one auxiliary. The larva has then reached a stage correlative with the goniatites of the Upper Carboniferous. This period of growth did not last long, for shortly after the appearance of the constriction which marks the end of the first coil the septa lose their goniatitic character and become transitional to the ammonite stage. This is shown on Pl. XXVII, figs. 3 and 4 , and the outside form of the shell on P1. XXIV, figs. 6 and 7. At one and one-twelfth coils the shell is transitional from the glyphioceran stage (Pronannites) to what resembles closely the genus Nannites of the Trias, as

${ }^{1}$ Haug, "E,tudes sur les Goniatites", p. 27, fig. 6, e, shows Pericyclus with two internal lateral lobes, but this was wrongly copied from Holzapfel's original drawing, "Carbon- Kalke von Eirdbach", P1. III, fig. 6, where only one internal lateral lobe is shown. 
shown on Pl. XXIV, figs. 8 and 9; the dimensions at this stage were as follows:-

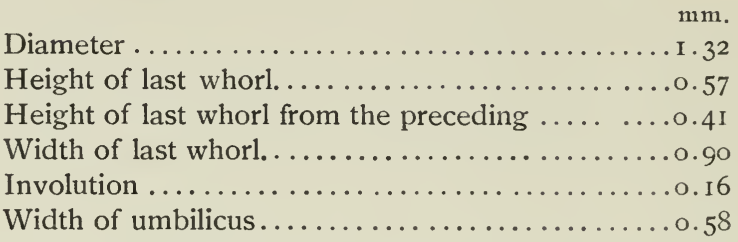

If it had not been said that this was a minute young shell taken out of an older individual, any paleontologist would refer it without hesitation to the Glyphioceratidæ, and probably to that group designated by Haug ( 1898 , p. 40) as Pronannites, of the Lower Carboniferous; the only character in which it differs from that group is in the two internal lateral lobes, and this, in the opinion of the writer, is the result of unequal acceleration, causing the introduction into the glyphioceran stage of elements that belonged to the descendants of this group. Moreover, there must have been some adult form with this character, for Paralegoceras has three external lateral lobes, and must have developed out of a form with glyphioceran or gastrioceran shape and the supernumerary internal lobes, since the new elements usually develop inside the umbilicus. This stage ends at one and one-fourth coils, diameter $1.50 \mathrm{~mm}$, having lasted about one-half a revolution.

\section{Adolescent Stages.}

Ananeanic-Cymbites Stage.-When the young animal has taken on characters that, if occurring in an adult, would stamp it as an ammonite and not a goniatite, it may be considered as adolescent; by this it is not meant to imply that there is any sharp line of demarcation between these two groups, for there are a number of genera that might, with equal propriety, be classed in either division; it is admitted, too, that this manner of subdividing ontogenic stages is artificial, and that it would be much more satisfactory merely to call a stage by the name of the genus with which it is correlated, if we could only be sure of this correlation. But, on account of unequal acceleration, and obscure 
development of characters in young ammonites, it is usually impossible to correlate them with certainty with any particular ancestral genus. And this difficulty increases when we leave the larval stages, and are concerned with later growth.

The ananeanic stage begins at one and a-quarter coils, diameter I.50 mm., when the pointed lateral lobe develops round prolongations on each side and becomes trifid (triænidian); about the same time the lateral saddle becomes indented, showing the first indication of digitation of the septa. Sculpture appears on the shell here for the first time, at first apparently merely a repetition of the constrictions and varices that began at the end of the first coil, then developing faint but distinct ribs between the constrictions. The septa at this stage are shown on Pl. XXVII, fig. 5, one and three-eighths coils, and of the following dimensions:-

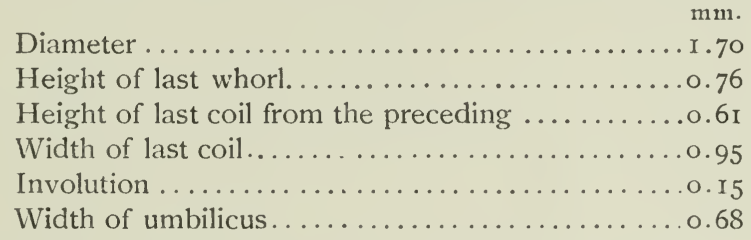

This first adolescent stage resembles greatly Cymbites, Diaphorites, and Pimelites, any one or all of which may well have been ancestors of the ægoceran stock, although it is impossible to speak with certainty or even probability, especially since the relations of these genera to each other are, as yet, only conjectural; the writer agrees with Buckman (I898), who regards Cymbites as the radicle of the ægoceran stock, but makes no mention of the other genera. This stage will be referred to as the Cymbites stage.

On Pl. XXIV, figs. IO and II, is figured a specimen of $P$. pacificum in the Cymbites stage, one and seven-twelfths coils and of the following dimensions:-

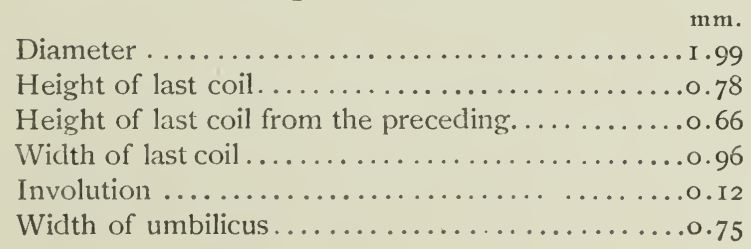


Hyatt (I889) thought that Neumayr's genus was founded on immature specimens, probably of the genus Agassizceras, while Haug does not think that the characters upon which the genus was based are sufficiently constant to warrant the separation. But whether Cymbites is a valid genus or not, there must have been such a form in the ancestral line of the Agoceratidæ, and thus of Hoplites and Placenticeras. So the name will be used until the genus is given a name that will stand, in case the old designation is thrown out.

Cymbites has been found only in the Lower Jura, but from its character must have occurred also in the Trias, for it is simpler in septa than any other ammonite of the Jura. This stage lasts in Placenticeras about three-eighths of a coil and ends at diameter $2.20 \mathrm{~mm}$., one and five-eighths of a coil from the protoconch.

Agoceran Stage.-With the beginning of this part of the adolescent stage the division of the lateral lobe becomes more pronounced, and a secondary indentation begins on the side away from the abdomen. The whorl grows higher, and the rounded exterior gives place to somewhat flattened sides with abdominal shoulders. The sculpture becomes stronger, and the shell is already decidedly ægoceran in appearance. The specimen figured on Pl. XXIV, figs. I2 and I3, and the septa on Pl. XXVII, figs. 6-8, show three internal lateral lobes, an advance in development that is more forward than that of Hoplites dufrenoyi at diameter $5.00 \mathrm{~mm}$. At one and seven-eighths coils the young ammonite gave the following dimensions (Pl. XXIV, figs. I 2 and I3) :-

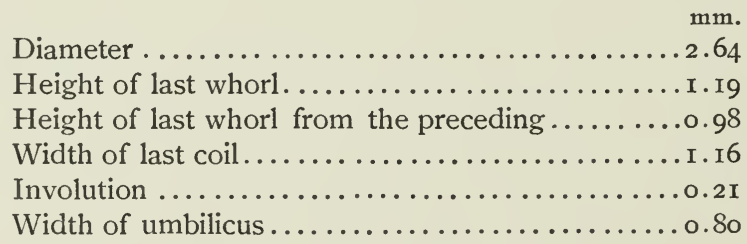

Perisphinctoid Stage. - At two revolutions, diameter $3.00 \mathrm{~mm}$., the sides become still more flattened and the abdominal shoulders. squarer, giving a perisphinctoid aspect, heightened by the frequent varices and the strong 
intermediate ribs on the sides and abdomen. It should be noted that the development of the septa has not kept pace with the other characters, for in small adolescent stages of ammonites, on account of their minute size and the thickness of the shell, it is physically, impossible for the septa to have the complexity of the corresponding adult genus. Another reason is that the retardation in development of the septa, which is distinctive of Placenticeras, begins to show itself here. This retardation becomes more pronounced as the stages advance, so that it becomes more than mere unequal acceleration of characters, for in the septa the Hoplites stage of development is never reached, the differentiation of the first lateral lobe into three secondary lobes being already complete. This differentiation shows itself quite distinctly in the perisphinctoid stage. The other characters are not affected by retardation to nearly so great an extent as the septa, or it may be more correct to state that retardation can not be detected in the other characters.

A specimen of two and a-quarter coils, figured on Pl. XXIV, figs. I4 and I5, gave the following dimensions:-

$\mathrm{mm}$.

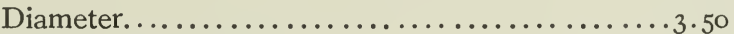

Height of last whorl.....................63

Height of last whorl from the preceding ...........36

Width of last whorl........................ 40

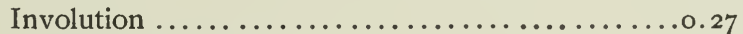

Width of umbilicus ....................... 6

In everything but the comparative simplicity of the septa this stage is distinctively perisphinctoid, but cannot be correlated with any particular genus of that group; especially in view of the fact that according to the researches of Buckman, quoted above, Perisphinctes itself is a degenerate of the stock of the Stephanoceratidæ. The perisphinctoid stage lasts up to two and a-quarter coils, diameter about $3.50 \mathrm{~mm}$.

Metaneanic-Cosmoceras Stage.-In this stage the ribs no longer cross the abdomen, but end in tubercles on the abdominal shoulders, forming well defined shoulder keels, with a furrow between them. The varices and constrictions cease abruptly with the beginning of the stage, at about two and a-quarter coils. The ribs become faint on 
the sides, but are strong on the umbilicus and on the shoulders, giving a strong resemblance to Cosmoceras, which increases as the stage advances. The septa at first are comparatively simple, although ammonitic. The first lateral lobe begins to lose its identity as a separate lobe, the three divisions of this becoming independent. The outside indentation of the external saddle also begins to assume the proportions of an independent lobe. At the beginning of the stage there are four external primary lateral lobes, and three internal; but about the middle of the third coil, diameter $4.50 \mathrm{~mm}$., the indentation of the external saddle, and the three divisions of the large primary lateral lobe assume the proportions of independent lobes, their arrangement in a curve showing their secondary nature. This is shown on Pl. XXVII, figs. IO-I3, where the septa are seen to be remarkably like those of Diaphorites Fucini, (Pl. XXVIII, fig. 7), although the shell has long since passed through the stage resembling Diaphorites. This is a rather unusual way for new elements to be added to the septa, they usually coming in at the umbilicus. As a consequence of this mode of addition the complexity does not decrease from the abdomen towards the umbilicus, but decreases both ways from the middle of the sides. It would be hard for one that had seen only the adult to believe that the first four lateral lobes had been developed out of one primary lobe. A somewhat similar development has been observed by the writer in the Pinacoceratidæ.

While the almost smooth sides, the strong abdominal shoulder keels made up by growing together of tubercles at the outer ends of the ribs, the narrow umbilicus, and the high narrow whorl all show affinities with Cosmoceras, the septa never reach, during this stage, the complexity of that genus. This may be due either to the greater acceleration of development of the form and ornamentation of the shell, or to the physical impossibility of having a chamber-wall take on so many convolutions at the edge in so small a space. Most probably the former explanation is the correct one. A specimen of this stage is figured on 
P1. XXIV, figs. 16 and 17 , two and three-eighths coils, and of the following dimensions:-

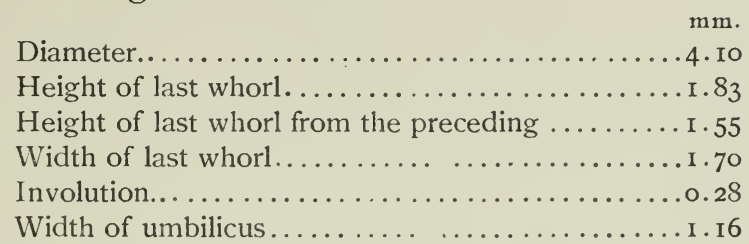

On this specimen the Nannites stage was seen on the second coil, the perisphinctoid stage on the third coil up to diameter $3.60 \mathrm{~mm}$., two and a quarter coils, while the cosmoceran stage begins just after the last constriction visible on the shell, and lasts up to the end of the third coil, diameter about $7 \mathrm{~mm}$. In this stage the shell resembles a species included by some paleontologists in the genus Oppelia, Ammonites bipartitus Zieten, as figured by Quenstedt in "Ammoniten des Schwäbischen Jura", Pl. LXXXV; but Quenstedt included that species under the Ornati, and evidently considered it as a Cosmoceras.

A larger specimen in the Cosmoceras stage is figured on Pl. XXIV, figs. I8, I9, showing the distinct bundling of the ribs on the sides, and the coarse abdominal tubercles; this specimen at two and five-sixths coils showed the following dimensions :-

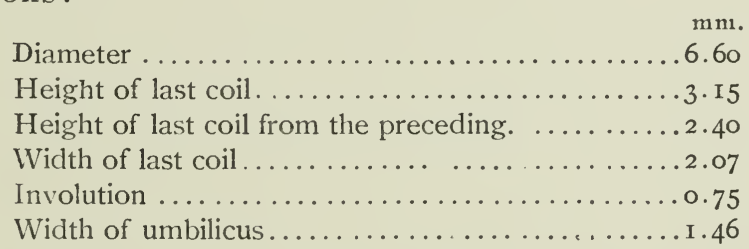

On this specimen the body-chamber occupied two-thirds of the last coil, and was incomplete even then; the last half coil was taken up by the cosmoceran stage, and the first half by the ægoceran and the perisphinctoid stages.

Just how long the cosmoceran stage lasts or when it ends it is impossible to say, because the change into the next stage is so gradual, and because it comes at such different sizes on different individuals. Since the characters of any one generic stage do not appear or disappear all at once, on account of unequal acceleration of development of these 
characters, no one stage is exactly correlative with any particular genus. Thus in naming the stages after genera, it is merely meant that the characters of those genera are predominant. This effect of unequal acceleration becomes more marked as the adolescent stage advances. Near the end of this stage appears the central abdominal keel of Placenticeras.

Paraneanic-Hoplites Stage.-Near the beginning of the fourth coil, diameter slightly over $8 \mathrm{~mm}$, the ribs are reduced to mere faint undulations and fine sickle-shaped striæ on the sides and umbilicus, while the external tubercles become almost obsolete, forming mere notches on the continuous abdominal keels. Specific characters begin to appear here, and there is no longer any doubt as to the family to which it belongs; this may be considered as the beginning of the Hoplites stage. The septa have not yet reached the complete development of the genus, although on Pl. XXVIII, figs. I and 2, a considerable advance over the Cosmoceras stage may be seen, especially in the digitation of the secondary lobes. A perfect specimen of three and a half coils, figured on Pl. XXIV, figs. 20 and 21 , showed the transition from the cosmoceran to the Hoplites stage, and gave the following dimensions:-

Diameter ........................ $\mathrm{mm}$.

Height of last whorl................... 7.00

Height of last whorl from the preceding...... 5.50

Width of last whorl. ....................... 3.60

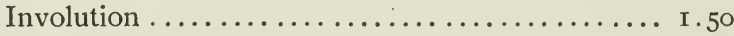

Width of umbilicus.................... 2.00

With this stage begin the umbilical knots, which persist and grow stronger, being characteristic of the mature Placenticeras; the sculpture becomes fainter, and the tubercles on the shoulder keels subside into faint notches; at the same time the lateral compression becomes more pronounced, and the shell becomes discoidal and very high-whorled. Placenticeras pacificum at this stage is wholly unlike $P$. californicum, with which it is associated, being much more compressed and discoidal, with narrower abdomen, flatter sides, much less distinct sculpture, and narrower umbilicus, 
although in the earlier adolescent periods both species are very much alike. This stage of growth is most nearly related to Hoplites splendens of the Gault, Lower Cretaceous, of Europe, but differs from it in being more compressed laterally, in the narrower abdomen, and the smoother abdominal keels, which on $H$. splendens have a row of tubercles like the adolescent stage of Placenticeras pacificum. The septa of the European species differ considerably from those of the Californian, showing none of the degeneration in the approach to Placenticeras, which genus, according to Douvillé ( 1890, p. 290), is a descendant of Hoplites.

In the adolescent stage the four secondary lobes, formed from the first lateral by subdivision, swing more and more out of the original curve, and finally in maturity all semblance of the original lobe is lost. The septa then begin to bear some resemblance to Placenticeras, as does also the shape of the whorl, and the lack of marked sculpture of the shell. This species is now evidently on the road to becoming a Placenticeras, although it has not yet reached that stage of development; this seems to confirm the conjecture of Douvillé as to the origin of that genus, which was formerly classed with the Amaltheidæ.

\section{Ephebic or Adult Stage.}

When the septa have reached the characters of Placenticeras, and undergo no further generic development, the adult stage may be said to have begun. But these characters begin singly, so there is no sudden transition from Hoplites to Placenticeras. Retardation in development of the septa shows itself early in the adolescent period, and grows more marked as the stage advances, so that the full generic development of Hoplites is never reached. At the diameter of $15 \mathrm{~mm}$. the septa have already attained the development of Placenticeras, while the shell is decidedly a Hoplites. But when the shell becomes extremely discoidal, the umbilical knots strong, the lateral sculpture weak, and the central and marginal ventral keels a decided feature, the shell is no longer comparable to any 
species of Hoplites, even though many characters of that genus still remain. This may be called the transition to Placenticeras.

A specimen with the transition just beginning is figured on Pl. XXV, figs. 9 and Io, four coils, and diameter 20.5 mm., showing the fine sculpture, sharp, slightly notched marginal keels, and narrow umbilicus with faint nodes. A cross-section of this stage is shown on Pl. XXVIII, fig. 5 . This stage continues unchanged to four and five-eighths

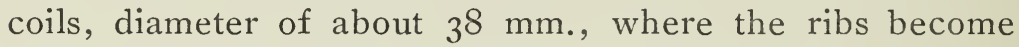
suddenly coarse, and undulating nodes begin to show on the marginal keels. A specimen of this stage is figured on Pl. XXV, fig. II, showing the sudden transition from fine to coarse sculpture. Now, for the first time, this species can certainly be placed among the typical members of Placenticeras, as defined by Meek, so the transition period is over, and the animal is really mature in characters, although not yet in size, since it grows nearly five times as large, and adds many more specific characters. This stage continues unchanged for nearly a revolution, the septa growing somewhat more complex, but advancing little beyond those seen at diameter of $15 \mathrm{~mm}$. The septa, at the latest stage where they were visible, five and a-third coils, are shown on $\mathrm{Pl}$. XXVIII, fig. 4. The septa of $P$. guadaloupe Roemer, copied on Pl. XXVIII, fig. 8, show a decided resemblance to those of $P$. pacificum, but are more finely digitate, and have two more auxiliary lobes; but the arrangement of the three principal lateral lobes in a backward-pointing curve is suggestive of a similar secondary origin. Placenticeras placenta Dekay has departed still further from the parent type and has its lobes arranged almost in a straight line, and this character is pushed back by acceleration of development until it is seen even in the larval stages, as shown by Jackson (I899, Pl. $\mathrm{XXV}$, figs. II 8 and II9). The early larval stages were not figured, so it is not possible to be sure that the lateral lobes developed by subdivision, but this is very probably the case.

In extreme maturity the central abdominal keel becomes obsolete, and the fine notches on the marginal keels are transformed into rough elongated nodes; the ribs become 
coarser, with deeper furrows separating them, crossing even the flattened abdomen. The species now begins to have considerable resemblance to $P$. placenta, although not more than every member of a genus ought to show to the type, but it never departs so far from the Hoplites group as does $P$. placenta. The characters of extreme maturity begin at about five and two-thirds coils, diameter II $8 \mathrm{~mm}$; how long they lasted, or whether there was any further change it is impossible to say, as the largest specimen seen had diameter I72 mm., and still showed no senile degeneration, unless the widening of the umbilicus is due to deficiency of growth force. This specimen is the type of the species (Pl. XXVI); it is the property of Mr. F. M. Anderson, of Yreka, California.

The genus Sphenodiscius was included by Meek as a subgenus under Placenticeras, and has been considered by Douville as having a common origin with that group in Hoplites; both genera seem to have had their origin during the upper part of the Lower Cretaceous, but Sphenodiscus does not seem to have been either ancestor or descendant of Placenticeras, and, therefore, cannot be considered as a subgenus under it.

Placenticeras shows retardation and degeneration, but Sphenodiscus has departed still further from the parent type; its secondary lobes have swung more nearly into a straight line, and have become simpler, by retardation, until they are almost ceratitic in character. But this simplification of the septa can not be referred to reversion to any ancestral characters, since they were never present in any of its ancestors. The ontogeny of this genus is unknown, but it will probably show the larval and earliest adolescent stages normal in number and character of lobes, and with this subdivision into secondary lobes pushed by acceleration of development to an early stage. The life-history of Spheno discus would then repeat a part of the ontogeny of Hoplites, but can not give the complete record. 


\section{Table of Cross-Section of Placenticeras pacificum.}

\begin{tabular}{|c|c|c|c|c|c|c|c|c|c|}
\hline & స్ & 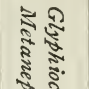 & $\begin{array}{c}5 \\
5 \\
5 \\
5 \\
5 \\
5 \\
5 \\
5 \\
5\end{array}$ & 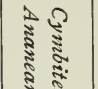 & 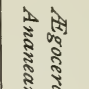 & 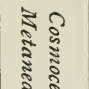 & \multicolumn{3}{|c|}{ Hoplites Stage Paraneanic. } \\
\hline & $\begin{array}{l}\text { Proto- } \\
\text { conch. }\end{array}$ & $1 / 2$ coil. & I coil. & I $1 / 2$ cls. & 2 coils. & $21 / 2 \mathrm{cls}$. & 3 coils. & $3 \frac{1}{2}$ coils. & 4 coils. \\
\hline Diameter ... & $\mathrm{mm}_{0.6 \mathrm{I}}$ & $\underset{\mathrm{mm}}{\mathrm{m}}$ & $\mathrm{mm}_{\mathrm{I} .2 \mathrm{I}}$ & $\lim _{\mathrm{I} .79}$ & $\operatorname{mm}_{2.65}$ & $\min _{4.22}$ & $\mathrm{mmi}_{7.00}$ & $\begin{array}{l}\mathrm{n} 1 \mathrm{~m} . \\
\mathrm{I} 2.00\end{array}$ & $\begin{array}{l}\mathrm{mm} . \\
20.75\end{array}$ \\
\hline $\begin{array}{c}\text { Height of last } \\
\text { whorl .... }\end{array}$ & $\sigma^{\circ}$ & 0.48 & 0.49 & 0.64 & $0.9^{8}$ & I.95 & 3.48 & 6.20 & II .00 \\
\hline $\begin{array}{l}\text { Height of last } \\
\text { whorl from the } \\
\text { preceding. . }\end{array}$ & . . & 0.27 & 0.33 & 0.58 & 0.86 & I. 57 & 2.82 & 5.00 & 8.70 \\
\hline $\begin{array}{c}\text { Width of last } \\
\text { whorl .... }\end{array}$ & 0.80 & 0.94 & 0.89 & 0.91 & I. I I & 1. 49 & I.99 & 3.15 & 5.25 \\
\hline Involution . . & . . . & $0.2 \mathrm{I}$ & 0.16 & 0.06 & 0.12 & 0.38 & 0.66 & 2.20 & 2.50 \\
\hline $\begin{array}{c}\text { Width of umbil- } \\
\text { icus ..... }\end{array}$ & $\cdot \cdots$ & . & 0.12 & $0.5^{8}$ & $0.9 \mathrm{I}$ & I. 24 & I. $5^{8}$ & 2.50 & 4.00 \\
\hline
\end{tabular}

Table of Stages of Growth of Placenticeras pacificum.

\begin{tabular}{|c|c|c|c|c|c|c|c|}
\hline & & & & & & $\begin{array}{l}\text { Sculp- } \\
\text { ture } \\
\text { begins. }\end{array}$ & $\begin{array}{l}\text { Lobes } \\
\text { become } \\
\text { ammo- } \\
\text { nitic. }\end{array}$ \\
\hline & $\begin{array}{l}\text { Phylem- } \\
\text { bryonic. }\end{array}$ & \multicolumn{2}{|c|}{$\begin{array}{l}\text { Ana- to Meta- } \\
\text { nepionic. }\end{array}$} & \multicolumn{4}{|c|}{ Paranepionic. } \\
\hline & $\begin{array}{l}\text { Nau- } \\
\text { tilian. }\end{array}$ & \multicolumn{2}{|c|}{ Glyphioceran. } & \multicolumn{2}{|c|}{$\begin{array}{l}\text { Transition to } \\
\text { Nannites. }\end{array}$} & \multicolumn{2}{|c|}{ Nannites. } \\
\hline & $\begin{array}{l}\text { Proto- } \\
\text { conch. }\end{array}$ & $\begin{array}{l}\text { P. and } 1 / 3 \\
\text { coil. }\end{array}$ & $\begin{array}{l}\text { P. and } 1 / 2 \\
\text { coil. }\end{array}$ & $\begin{array}{l}\text { P. and } 3 / 4 \\
\text { coil. }\end{array}$ & I coil. & $\begin{array}{l}\text { I I/I } 2 \\
\text { coils. }\end{array}$ & $\begin{array}{l}\text { I } 1 / 4 \\
\text { coils. }\end{array}$ \\
\hline & $\mathrm{mm}$. & $\mathrm{mm}$. & $\mathrm{mm}$. & $\mathrm{mm}$. & $\mathrm{mm}$ & $\mathrm{mm}$. & $\mathrm{mm}$ \\
\hline Diameter ....... & 0.54 & 0.76 & 0.83 & 0.98 & I.16 & I.32 & I. 57 \\
\hline Height of last coil ... & $\ldots$ & $0.4 \mathrm{I}$ & 0.34 & 0.33 & 0.38 & 0.57 & 0.65 \\
\hline $\begin{array}{c}\text { Height of last coil from } \\
\text { the preceding ..... }\end{array}$ & $\ldots$ & 0.28 & 0.25 & 0.25 & 0.32 & $0.4 \mathrm{I}$ & 0.53 \\
\hline Width of last coil . . . & 0.75 & 0.86 & 0.80 & 0.80 & 0.72 & 0.90 & 0.90 \\
\hline Involution $\ldots \ldots \ldots$ & $\cdots$ & 0.13 & 0.09 & 0.08 & 0.06 & 0.16 & 0.12 \\
\hline Width of umbilicus ... & ... & . . & 0.26 & 0.23 & 0.46 & 0.58 & 0.61 \\
\hline
\end{tabular}




\begin{tabular}{|c|c|c|c|c|c|c|c|c|}
\hline & $\begin{array}{c}\text { Distinct } \\
\text { ribs } \\
\text { begin. }\end{array}$ & $\begin{array}{c}\text { First } \\
\text { lateral } \\
\text { lobe be- } \\
\text { comes } \\
\text { trifid. }\end{array}$ & & & $\begin{array}{l}\text { Whorl } \\
\text { be- } \\
\text { conies } \\
\text { helmet- } \\
\text { shaped. }\end{array}$ & & \multicolumn{2}{|c|}{$\begin{array}{l}\text { Sides and abdo } \\
\text { men flatten, and } \\
\text { the s houlders } \\
\text { become distinct }\end{array}$} \\
\hline & \multicolumn{8}{|c|}{ Ananeanic. } \\
\hline & \multicolumn{4}{|c|}{ Cymbites. } & \multicolumn{2}{|c|}{ Agoceran. } & \multicolumn{2}{|c|}{ Perisphinctoid. } \\
\hline & $\begin{array}{l}13 / 8 \\
\text { coils. }\end{array}$ & $\begin{array}{l}11 / 2 \\
\text { coils. }\end{array}$ & $\begin{array}{l}\text { I } 7 / 12 \\
\text { coils. }\end{array}$ & $\begin{array}{l}12 / 3 \\
\text { coils. }\end{array}$ & $\begin{array}{l}13 / 4 \\
\text { coils. }\end{array}$ & $\begin{array}{l}17 / 8 \\
\text { coils. }\end{array}$ & 2 coils. & $\begin{array}{l}21 / 4 \\
\text { coils. }\end{array}$ \\
\hline & $\mathrm{mm}$. & $\mathrm{mm}$ & $\mathrm{mm}$ & $\mathrm{mm}$ & $\mathrm{mm}$ & $\mathrm{mm}$ & $\mathrm{mm}$ & $\mathrm{mm}$. \\
\hline Diameter....... & 1.70 & 1.82 & 1.99 & 2.20 & 2.40 & 2.64 & 2.82 & $3 \cdot 50$ \\
\hline Height of last coil . . . . & 0.76 & 0.79 & 0.78 & 0.91 & 0.94 & I.19 & 1.29 & I.63 \\
\hline $\begin{array}{l}\text { Height of last coil from } \\
\text { the preceding } . . .\end{array}$ & $0.6 \mathrm{I}$ & 0.60 & 0.66 & $0.7 \mathrm{I}$ & 0.79 & 0.98 & 1.08 & I. 36 \\
\hline width of last coil ..... & $\begin{array}{c}0.95 \\
\text {. }\end{array}$ & 0.98 & 0.96 & 1.04 & I.08 & I. 16 & I.2I & I.40 \\
\hline Involution $\ldots \ldots$ & 0.15 & 0.19 & 0.12 & 0.20 & 0.15 & $0.2 \mathrm{I}$ & 0.21 & 0.27 \\
\hline Width of umbilicus . . & 0.68 & 0.65 & 0.75 & $0.8 \mathrm{I}$ & 0.83 & 0.80 & 1.00 & 1.06 \\
\hline
\end{tabular}

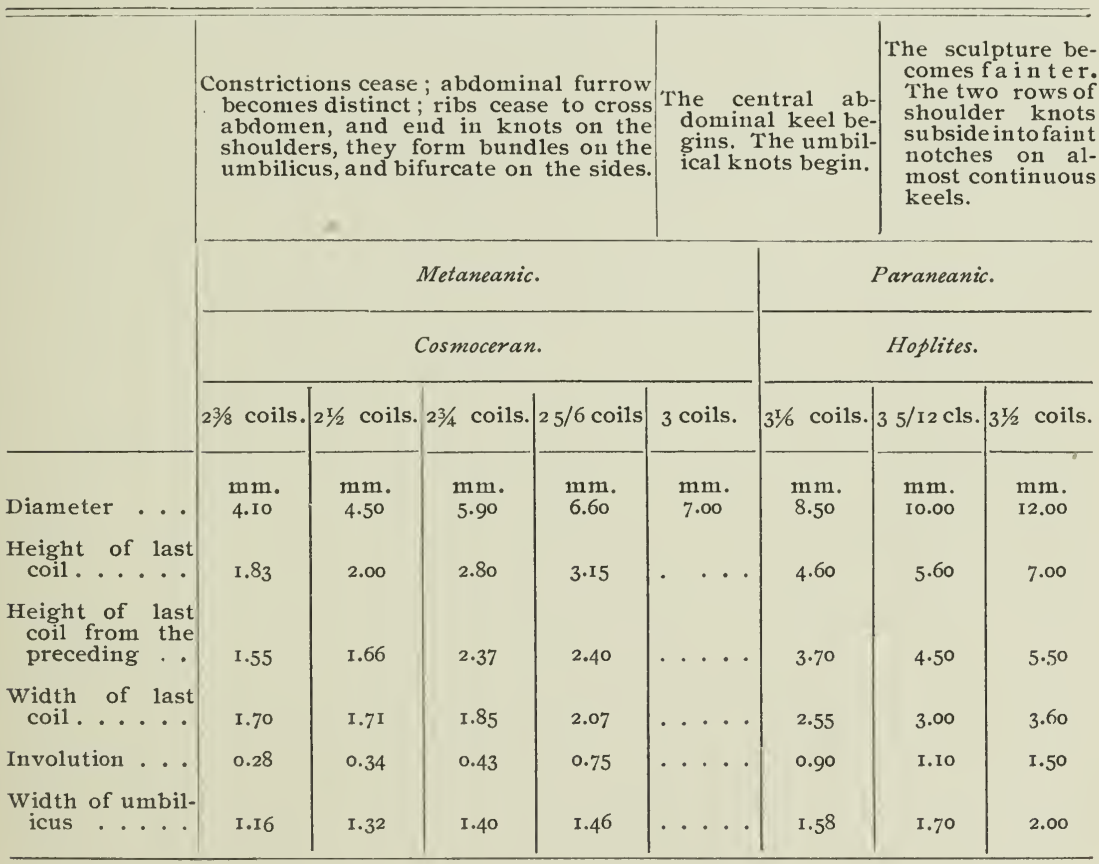




\begin{tabular}{|c|c|c|c|c|c|c|c|c|}
\hline & \multirow{2}{*}{\multicolumn{4}{|c|}{$\begin{array}{l}\text { The septa begin to resemble } \\
\text { Placenticeras. }\end{array}$}} & \multicolumn{2}{|c|}{$\begin{array}{l}\text { The fine sickle- } \\
\text { shaped ribsbe- } \\
\text { conie suddenly } \\
\text { coarse. }\end{array}$} & \multicolumn{2}{|c|}{$\begin{array}{l}\text { The notched keels } \\
\text { give place to strong, } \\
\text { elongated nodes, and } \\
\text { the central keel dis } \\
\text { appears. }\end{array}$} \\
\hline & & & & & Metep & hebic. & Paref & shebic. \\
\hline & \multicolumn{4}{|c|}{$\begin{array}{l}\text { Transition from Hoplites to } \\
\text { Placenticeras. }\end{array}$} & \multicolumn{4}{|c|}{ Placenticeras. } \\
\hline & $3 \frac{3}{4}$ coils. & 4 coils. & $4^{1} / 4$ coils. & $4 \frac{1}{2}$ coils. & $45 / 6$ coils & $5^{1 / 6}$ coils. & $5^{2 / 3}$ coils. & $61 / 6$ coils \\
\hline viameter ... & $\begin{array}{l}1 \mathrm{n} 111 . \\
\mathrm{I} 5.00\end{array}$ & $\mathrm{nmm}_{20.50}$ & $\begin{array}{l}\min \\
26.50\end{array}$ & $\mathrm{~mm}$. & $\begin{array}{c}11111 \\
4700\end{array}$ & $\min _{67.00}$ & $\underset{\mathrm{I} 18.00}{\min }$ & $\underset{\mathrm{I} 72.00}{\mathrm{~mm}}$ \\
\hline $\begin{array}{c}\text { Height of last } \\
\text { co1l..... }\end{array}$ & 8.00 & Io. 80 & 14.00 & I 8.00 & 22.50 & 36.00 & 60.00 & 74.00 \\
\hline $\begin{array}{l}\text { Height of last } \\
\text { coil from the } \\
\text { preceding }\end{array}$ & 6.50 & 9. Io & II. 50 & 15.00 & 18.00 & ... . & . . & 52.00 \\
\hline $\begin{array}{c}\text { Width of last } \\
\text { coil..... }\end{array}$ & 4.00 & 5.00 & 6.75 & 7.75 & I 2.00 & 19.00 & 25.00 & 35.00 \\
\hline Involution . . & I. 50 & I. 70 & 2.50 & 3.00 & $4 \cdot 50$ & $\ldots$ & $\ldots$ & 22.00 \\
\hline $\begin{array}{l}\text { width of umbil- } \\
\text { icus .... }\end{array}$ & 2.50 & $3 \cdot 50$ & $4 \cdot 50$ & 6.00 & 9.00 & II. 50 & 19.00 & 35.00 \\
\hline
\end{tabular}

Conclusion and Summary of Results.

The development of Placenticeras shows that it is possible, in spite of dogmatic assertions to the contrary, to decipher the race history of an animal in its individual ontogeny. But the interpretation of ontogenic data is no simple problem of mere comparison of growth stages with antecedent genera; we must know the sources of error and apply the necessary corrections. We must guard against unequal acceleration, by which in the ontogeny of descendants characters are caused to occur together that belonged to different geologic generations of ancestors. An example of this is the central abdominal keel, that begins near the end of the cosmoceran stage, when no Cosmoceras nor even Hoplites ever had this; it is an adult character pushed back further than the other placenticeran characters by unequal acceleration. This inexact parallelism makes it impossible in many cases to correlate exactly a growth stage with the ancestral genus; otherwise it would be better to name the 
stage after the correlative genus, instead of using an arbitrary and artificial nomenclature such as has been adopted. When ontogenic stages are named after genera, it merely means that the characters of those genera are predominant.

Retardation plays an important part in the species discussed in this paper, showing itself especially in the septa, causing them to fail to reach the full development of Hoplites, the immediate ancestor of Placenticeras, and preventing individual ontogeny from giving the full ancestral record.

It is here demonstrated that new elements of the septa, contrary to the accepted belief, are sometimes added by subdivision of primary lobes on the outside, and not necessarily always in the part concealed by the involution, thus giving a reasonable explanation of the large number of small lobes found in such genera as Beloceras, Pinacoceras, and Sphenodiscus. The occurrence of lobes of this character does not show that such genera are related, but merely that each is a gerontic form, and that descendants of these are not to be expected in later formations. This does not apply to Arcestes, which has a large number of primary lobes, visible even on the second septum from the protoconch.

The stages wholly lost out of the ontogeny lie between the nautilian protoconch and the glyphioceran larval stage; this unrecorded part of the development is thought to have corresponded to the time spent in the egg. All later stages are recorded in ontogeny with a fair degree of distinctness.

The protoconch can not be correlated with any nautiloid, but the later stages can be compared with ammonoid genera, the exactness of the correlation becoming less as the stage advances, on account of unequal acceleration of development of ancestral characters, but on the other hand easier, on account of the greater number of characters one has to deal with.

The earliest larval stage is nautiloid in septa, but ammonoid in its calcareous protoconch. The middle larval stage is comparable with the Paleozoic group Glyphioceratidæ, probably Glyphioceras itself; the last larval stage is analogous to Nannites, a genus characteristic of the earliest Mesozoic. 
In the adolescent period Placenticeras goes through at first a stage corresponding to Cymbites, or at least some Cymbites-like form, of the Upper Trias; then to some ægoceran genus of Upper Triassic or Lower Jurassic age; then to some one of the earlier perisphinctoid genera; then to Cosmoceras of the Jura, and lastly to Hoplites of the Cretaceous. It is thus demonstrated by ontogenic study that Placenticeras developed out of Hoplites, and thus belongs with that group near the Stephanoceratidæ, and not under the Amaltheidæ, with which it is classed in nearly all text-books. This relationship is shown also by the number of ammonite species intermediate in character between Hoplites and Placenticeras, although they are conventionally grouped under one or the other genus.

It is a mistake to class Sphenodiscus as a subgenus under Placenticeras, for it is neither ancestor nor descendant of that genus, but a parallel, independent development from the common stock Hoplites. The same retardation that caused the peculiar arrangement of the lobes in Placenticeras has gone even further towards simplifying the septa of Sphenodiscus, although this can not correctly, in either case, be ascribed to reversion, since while both fail to reach, in some respects, the full development of their ancestors, they do not return to the characters of any of their predecessors.

A parallel study of the ontogeny of two closely related species shows that the results must be interpreted with caution. Placenticeras pacificum and P. californicum certainly came from the same group of Hoplites, and probably from the same species, but in the late adolescent stage they are unlike, just as easily distinguishable as at maturity, owing to pushing back of specific characters into the adolescent period. Even in the Cosmoceras stage the two are quite distinct; the difference becomes less in the perisphinctoid stage, and undoubtedly the larval stages would be precisely alike in both. But this does not mean that the line of descent was the same only through the larval stages, and that the two species branched out from different perisphinctoid forms, for in all probability the perisphinctoid, cosmoceran, 
and Hoplites ancestors were the same for both species, and the differentiation could not have taken place before the Lower Cretaceous; the difference is due to unequal acceleration of characters.

The development of Placenticeras gives us an unusually fine illustration of the law of acceleration, or tachygenesis, with its two corollaries, unequal acceleration and retardation. In species from the Paleozoic or early Mesozoic we get better correlations of growth stages with ancestral genera, for with them there is little unequal acceleration, and almost no retardation apparent. But they are usually so poorly preserved that this sort of work is impossible with them. In Cretaceous species the preservation is usually better and the young specimens may be taken out from the old in good state of preservation, and the comparison with supposed ancestral genera facilitated. But in these later genera, so far removed in time from their origin, the development is so much more complex, on account of unequal acceleration, and in some cases on account of retardation, that correlation with ancestral genera is no longer a simple problem, although all the more fascinating because of its difficulty; it calls to its aid all the resources of biology and geology

StanFord University,

CALIFORNIA,

March, I900. 


\section{BIBLIOGRAPHY.}

I885. Balfour, F. M. Treatise on Comparative Embryology.

1852. Barrande, J. Systéme Silurien du Centre de la Bohême. I Partie. I89i. Beecher, C. E. The Development of a Palæozoic Poriferous Coral. Trans. Connecticut Acad., Vol. VIII, pp. 207-2I4.

I89I-92. Development of the Brachiopoda. I and II. Amer. Journ. Sci., Vol. XLI and Vol. XLIV.

I893a. Revision of the Families of Loop-bearing Brachiopoda. Trans. Connecticut Acad., Vol. IX.

I893b. - Some Correlations of Ontogeny and Phylogeny in the Brachiopoda. Amer. Nat., Vol. XXVII, p. 603.

I895. - The Larval Stages of Trilobites. Amer. Geol., Vol. XVI.

I893. Beecher, C. E., ANd Schuchert, C. Development of the Brachial Supports in Dielasma and Zygospira. Proc. Biol. Soc. Washington, Vol. VIII, pp. 7 I -82 .

I895. Bernard, F. Traité de Paléontologie.

I896-97. Études comparatives sur la coquille des Lamellibranches. Jour. de Conchyl., Vol. XLIV, p. I69, and Vol. XLV, pp. 5-46.

I879. Branco, W. Beitraege zur Entwicklungsgeschichte der Fossilen Cephalopoden, I. Palcontographica, Vol. XXVI.

1892. Brown, A. P. The Development of the Shell in the Coiled Stage of Baculites compressus Say. Proc. Acad. Nat. Sci. Phila., I892, p. 139 .

I898. BuCKman, S. S. On the Grouping of some Divisions of so-called Jurassic Time, Quart. Journ. Geol. Soc., Vol. LIV, No. 215.

I887. Cope, E. D. Origin of the Fittest.

I89o. Douvillé, H. Sur la classification des Cératites de la Craie. Bull. Soc. Géol. France, 3d Ser., Tome XVIII.

1892. Fischer, P. and Oehlert, D. P. Brachiopodes. Mission Scientif. du Cap Horn, pp. 50-60.

I896. Fucini, A. Fauna d. Lias Medio del Monte Calvi. Pal. Ital., Vol. II.

I895. Girty, G. H. Development of the Corallum in Favosites Forbesi, var. occidentalis. Amer. Geol., Vol. XV, pp. I3I-I44.

1887. Haug, E. Ueber die Polymorphidæ. Neues Jahrb. f. Min., I887, Bd. II, p. 89.

I894. Les Ammonites du Permien et du Trias. Bull. Soc. Géol. France, 3d Ser., Tome XXII, p. 4II.

1898. Études sur les Goniatites. Mém. Soc. Géol. France, Paléontologie, Tome VII, No. r8.

I899. Holzapfel, E. Die Cephalopoden im Südlichen Timan. Mém. Com. Géol. St. Petersbourg, Tome XII, No. 3.

I866. Hyatт, A. Parallelism of Individual and Order among the Tetrabranchiate Mollusks. Mem. Boston Soc. Nat. Hist., Vol. I.

I872. Fossil Cephalopods of the Museum of Comparative Zoology. Embryology. Bull. Mus. Comp. Zool., Vol. III, No. 5.

I889. Genesis of the Arietidæ. Smithson. Contrib. to Knowledge, Vol. XXVI, No. 673 , pp. 66 and 95. 
1894. Hyatt, A. Phylogeny of an Acquired Characteristic. Proc. Amer. Phil. Soc., Vol. XXXII, No. I43, p. 405.

I89o. Jackson, R. T. The Phylogeny of the Pelecypoda, the Aviculidæ and their Allies. Mem. Boston Soc. Nat. Hist., Vol. IV, No. 8.

I895. - Studies of Palæechinoidea. Bull. Geol. Soc. Amer., Vol. VII, pp. I 7 I -254 .

1899. Localized Stages in Development in Plants and Animals. Mem. Boston Soc. Nat. Hist., Vol. V, No. 4, p. I 34.

1889. Karpinsky, A. Ueber die Ammoneen der Artinsk-Stufe. Mém. Acad. Impér. Sci. St. Petersbourg, 7th Ser., Tome XXXVII, No. 2.

1876. MEEk, F. B. Invertebrate Cretaceous and Tertiary Fossils of the Upper Missouri Country. Rept. U.S. Geol. Survey Terr., Vol. IX, p. 462.

1875. Neumayr, M. Die Ammoniten der Kreide und die Systematik der Ammonitiden. Zeitschr. d. Deutsch. Geol. Gesell.

I878. Ueber unvermittelt auftretende Cephalopodentypen im Jura Mittel-Europas. Jahrbuch d. K. K. Geol. Reichsanstalt Wien., Vol. XXVIII, p. 64.

189o. Nicklès, R. Contributions à la Paleontologie du Sud-Est de l'Espagne. Mém. Soc. Géol. France, Paléontologie, Tome I.

i889. Quenstedt, F. A. Die Ammoniten des Schwäbischen Jura.

I893. Sarasin, C. Étude sur les Oppelia du Groupe du Nisus et les Sonneratia du Groupe du Bicurvatus et du Rarisulcatus. Bull. Soc. Géol. France, 3d Ser., Tome XXI, p. I49.

I897. Quelques Considérationes sur les Genres Hoplites, Sonneratia, Desmoceras et Puzosia. Bull. Soc. Géol. France, 3d Ser., Tome XXV, pp. 760-799.

I897. Sмıтн, J. P. The Development of Glyphioceras and the Phylogeny of the Glyphioceratidæ. Proc. Calif. Acad. Sci., 3d Ser., Geol., Vol. I, No. 3 .

1898. The Development of Lytoceras and Phylloceras. Proc. Calif. Acad. Sci., '3d Ser., Geol., Vol. I, No. 4.

I899. - Larval Stages of Schlœenbachia. Journ. Morphol., Vol. XVI, No. I.

i89o. Steinmann, G. Elemente der Palæontologie.

i86i. Stoliczka, F. The Cretaceous Cephalopoda of Southern India. Mem. Geol. Survey India, Pal. Indica, p. 9o, Pl. XLVII, figs. I, 2; Pl. XLVIII, fig. I.

I865. Thomson, Sir W. On the Embryogeny of Antedon rosaceus. Philos. Trans. Royal Soc. London, Vol. CLIII.

I885. von ZitTel, K. A. Handbuch der Palæontologie, Bd. II.

1895. Grundzuege der Palæontologie. 


\section{EXPLANATION OF PLATE XXIV.}

\section{Placenticeras pacificum, sp. nov.}

Figs. I, 2. Protoconch from front and from above; 20 times enlarged. Arroyo del Vallé, Alameda County, California.

Fig. 3. Larval coil, diameter I.I6 mm., showing phylembryonic protoconch in the centre; 20 times enlarged. Arroyo del Valle, Alameda County, California.

Figs. 4, 5. Transition from phylembryonic to ana- to meta-nepionic stages, diameter $0.76 \mathrm{~mm}$., protoconch and one-third coil; 20 times enlarged. Arroyo del Vallé, Alameda County, California.

Figs. 6, 7. Protoconch and three-quarters of a coil, diameter $0.98 \mathrm{~mm}$, beginning of the paranepionic stage; 20 times enlarged. Arroyo del Vallé, Alameda County, California.

Figs. 8, 9. Paranepionic, transition from glyphioceran to Nannites, one and one-twelfth coils; 20 times enlarged. Arroyo del Vallé, Alameda County, California.

Figs. Io, II. Early adolescent (ananeanic), Cymbites stage, diameter I.99 mm., one and seven-twelfths coils; 13 times enlarged. Henley, Siskiyou County, California.

Figs. 12, I3. Ananeanic, ægoceran stage, one and seven-eighths coils, diameter $2.64 \mathrm{~mm}$.; ro times enlarged. Arroyo del Valle, Alameda County, California.

Figs. I4, I5. Ananeanic, perisphinctoid stage, diameter $3.50 \mathrm{~mm}$., two and a quarter coils; Io times enlarged. Arroyo del Vallé, Alameda County, California.

Figs. 16, I7. Metaneanic, transition from perisphinctoid to the cosmoceran stage, diameter 4. Io mm., two and three-eighths coils; Io times enlarged. Arroyo del Vallé, Alameda County, California.

Figs. I8, I9. Metaneanic, cosmoceran stage, diameter $6.60 \mathrm{~mm}$., two and three-quarters coils; 7 times enlarged. Arroyo del Valle, Alameda County, California.

Figs. 20, 21. Beginning of paraneanic stage, transition from cosmoceran to the Hoplites stage, diameter $\mathrm{r} 2 \mathrm{~mm}$., three and a half coils; 2.7 times enlarged. Henley, Siskiyou County, California. 

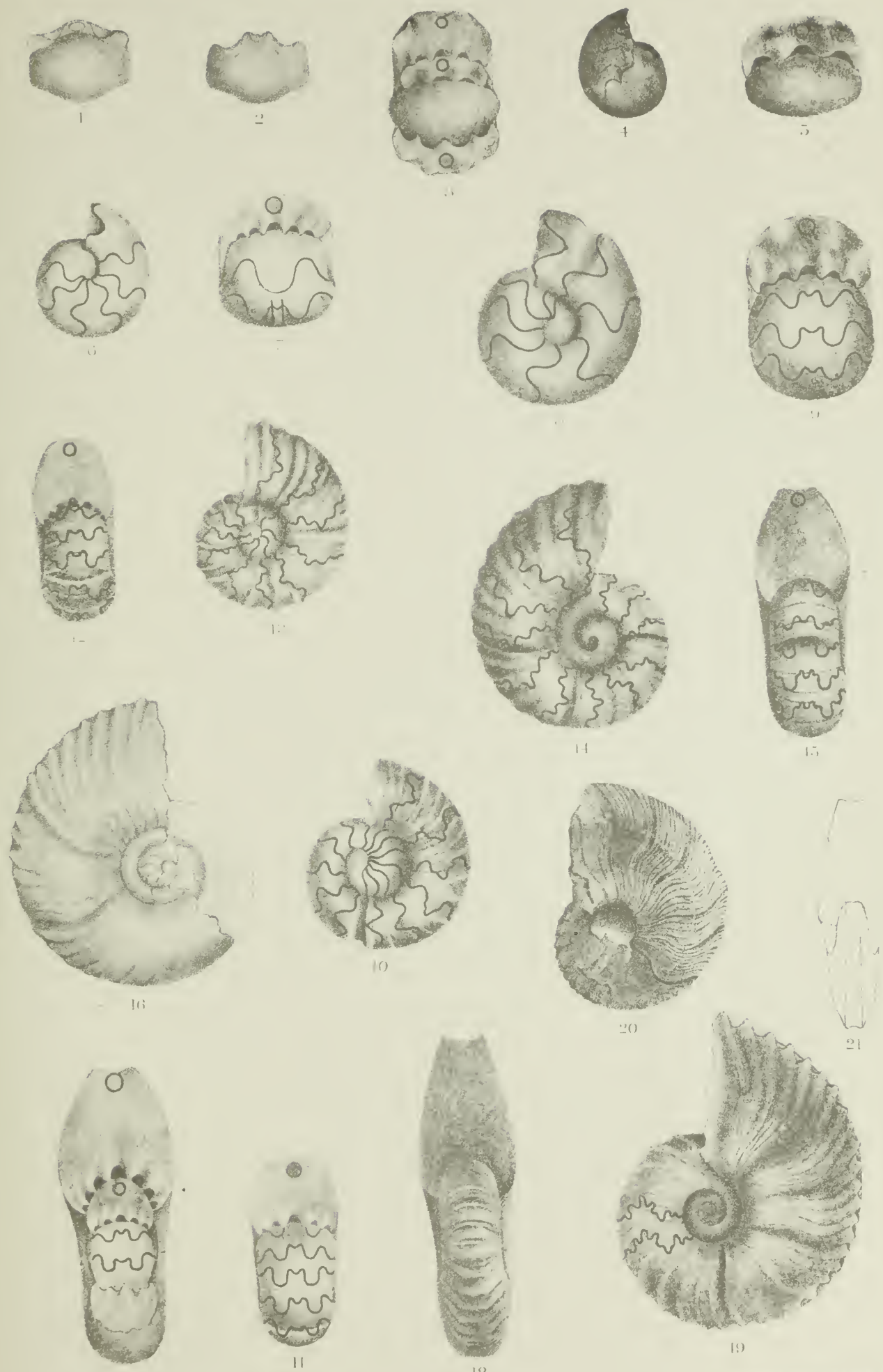




\section{EXPLANATION OF PLATE XXV.}

Figs. I, 2. Placenticeras californicum, adolescent, perisphinctoid stage, two and five-sixteenths coils, diameter $3.32 \mathrm{~mm}$.; io times enlarged. Henley, Caiifornia.

Fig. 3. P. californicum, adolescent, transition from cosmoceran to the Hoplites stage; three coils, diameter $8 \mathrm{~mm}$.; 2.7 times enlarged. Henley, California.

Figs. 4, 5. P. californicum, adolescent, typical Hoplites stage, three and five-eighths coils, diameter I4 mm.; twice enlarged. Henley, California.

Figs. 6, 7. P. californicum, adolescent, Hoplites stage, four coils, diameter $22 \mathrm{~mm}$.; twice enlarged. Arroyo del Vallé, Alameda County, California.

Fig. 8. P. californicum, transition from Hoplites to Placenticeras, four and a half coils, diameter $34.50 \mathrm{~mm}$.; twice enlarged. Henley, California.

Figs. 9, го. P. pacificum, end of Hoplites stage, four coils, diameter 20.5 mm.; 2.7 times enlarged. Arroyo del Vallé, California.

Fig. II. $\quad P$. pacificum, transition to Placenticeras, diameter $47 \mathrm{~mm}$., four and five-sixths coils; natural size. Henley, California. 

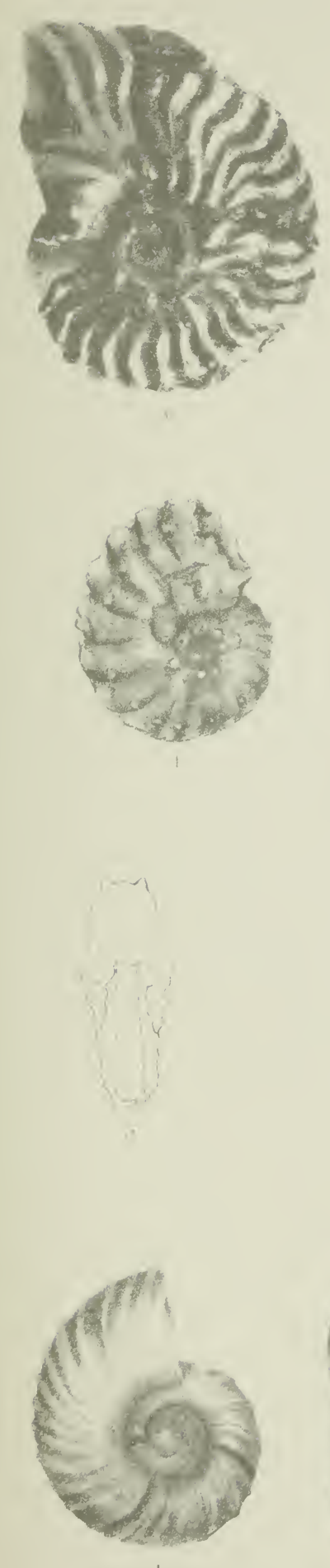
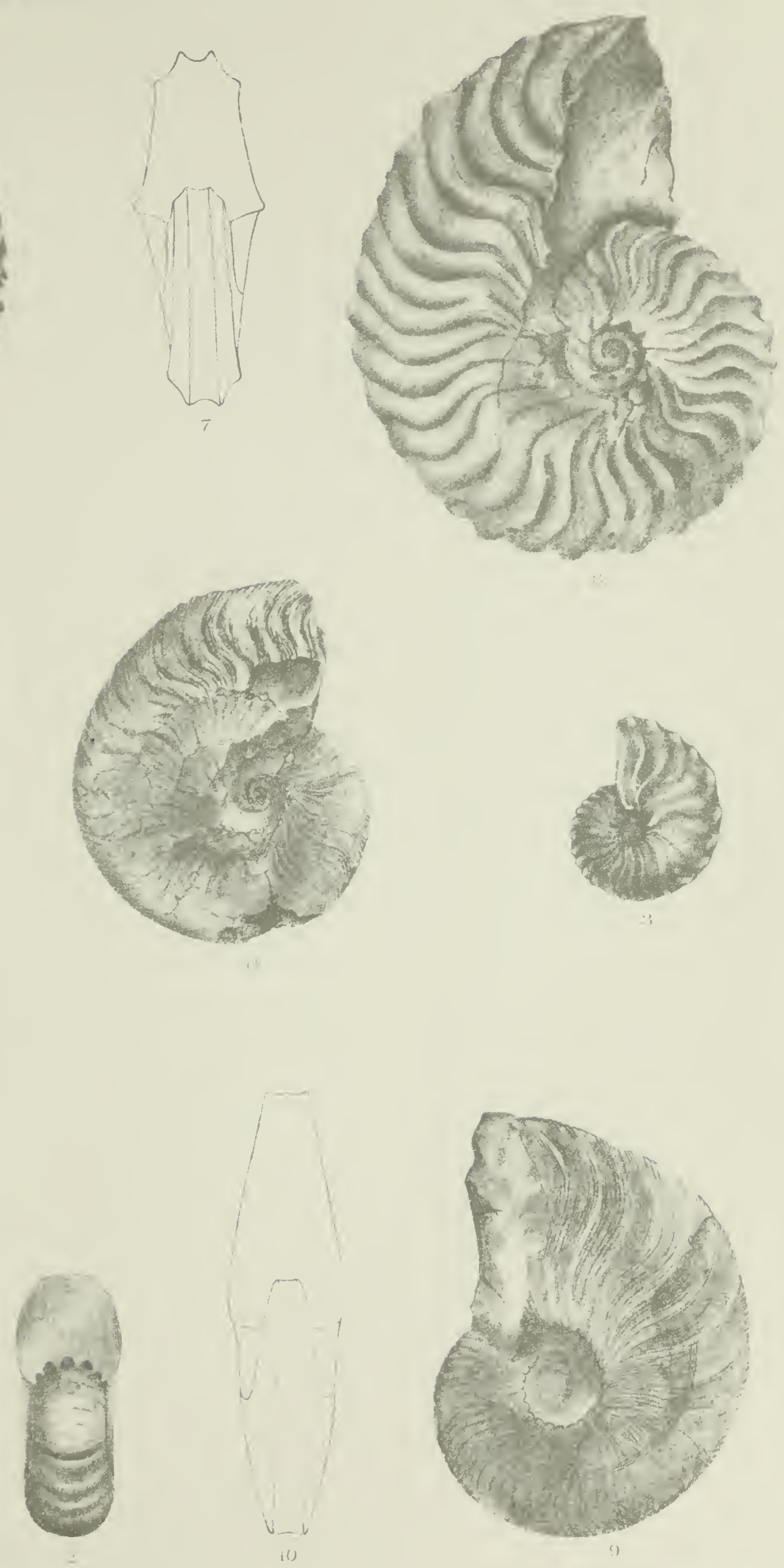


EXPLANATION OF PLATE XXVI.

(From a photograph by Franklin, Palo Alto, California.)

Placenticeras pacificum, sp. nov.

Adult shell, diameter $\mathrm{I} 72 \mathrm{~mm}$., six and a sixth coils, natural size. Henley, California. Type specimen, property of Frank M. Anderson, Yreka, California. 


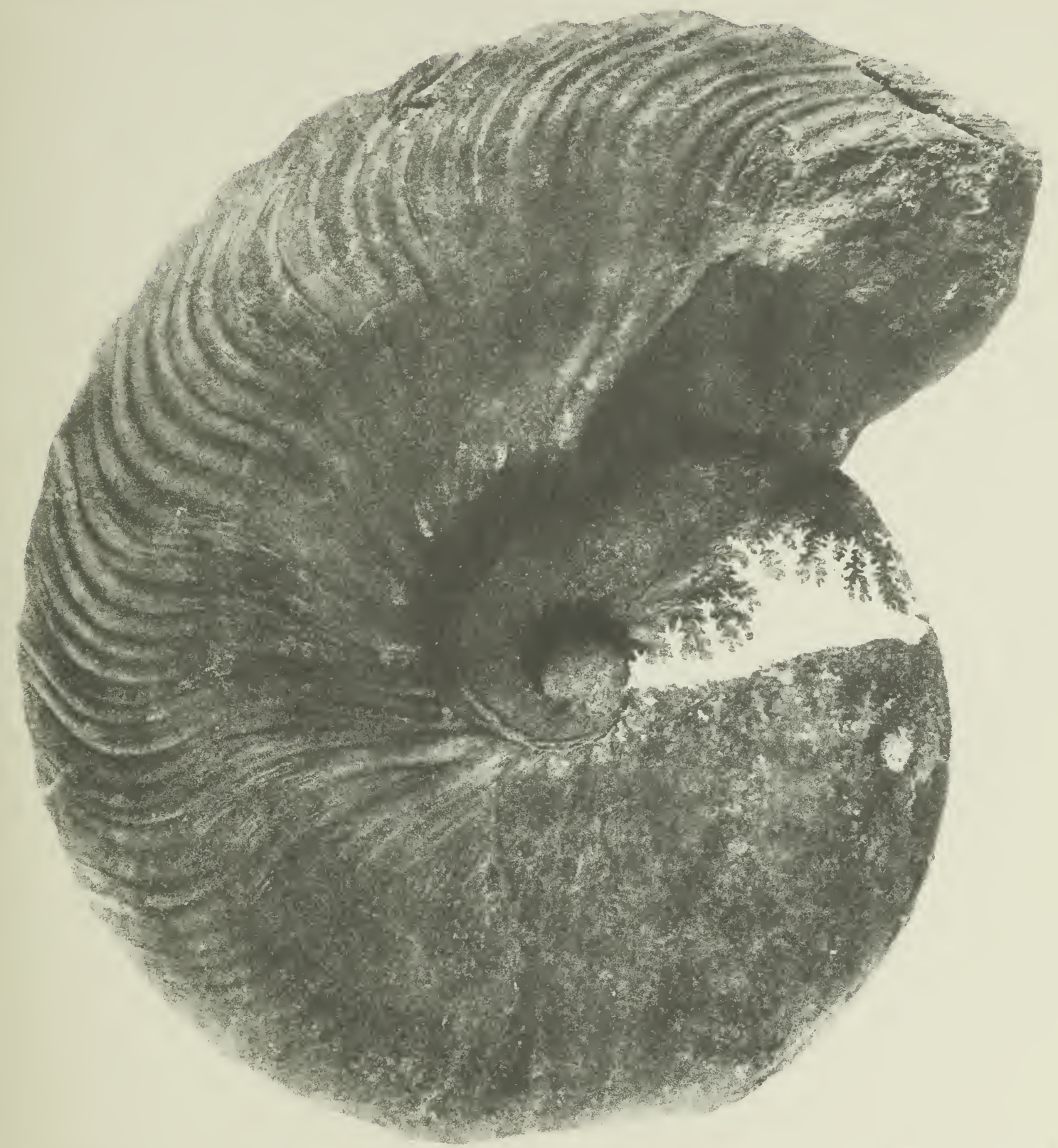

FliUTKW: $D E$. 




\section{EXPLANATION OF PLATE XXVII.}

Development of the Septa of Placenticeras pacificum.

Fig. I. First septum, ananepionic, nautiloid stage; 20/r.

Fig. 2. Septum at one-half coil, diameter $0.83 \mathrm{~mm}$., metanepionic, glyphioceran stage; $20 / \mathrm{r}$.

Fig. 3. Septum at one coil, diameter I.16 mm., glyphioceran stage; 20/I.

Fig. 4. Septum at one and one-twe I. $32 \mathrm{~mm}$., end of the paranepionic or end of larval stage, Nannites stage; 20/I.

Fig. 5. Septum at one and three-eighths coils, diameter $1.70 \mathrm{~mm} . ; 20 / \mathrm{I}$.

Fig. 6. Septum at one and five-eighths coils, diameter $2.20 \mathrm{~mm}$., $20 / \mathrm{I}$.

Fig. 7. Septum at one and three-quarters coils, diameter $2.40 \mathrm{~mm}$., $20 / \mathrm{r}$.

Fig. 8. Septum at one and seven-eighths coils, diameter $2.70 \mathrm{~mm}$., transitional from Egoceratidæ to the Perisphinctinæ; 20/1.

Fig. 9. Septum at two coils, diameter $3 \mathrm{~mm}$.; $20 / \mathrm{I}$.

Fig. Io. Septum at two and three-eighths coils, diameter 4. Io mm., Cosmoceras stage; $\mathrm{I} 3 / \mathrm{I}$.

Fig. II. Septum at two and a half coils, diameter $4.50 \mathrm{~mm}$., paraneanic, Cosmoceras stage; i4/I.

Fig. I2. Septum at two and seven-twelfths coils, diameter $5.50 \mathrm{~mm}$., Cosmoceras stage; $\mathrm{I} 4 / \mathrm{I}$.

Fig. I3. Septum at two and three-quarters coils, diameter $6.25 \mathrm{~mm}$., paraneanic, Cosmoceras stage; I/4/I. 


$$
\text { Whis }
$$

భนn

$$
\text { anisuras } \sin _{10}
$$

భ

นrin
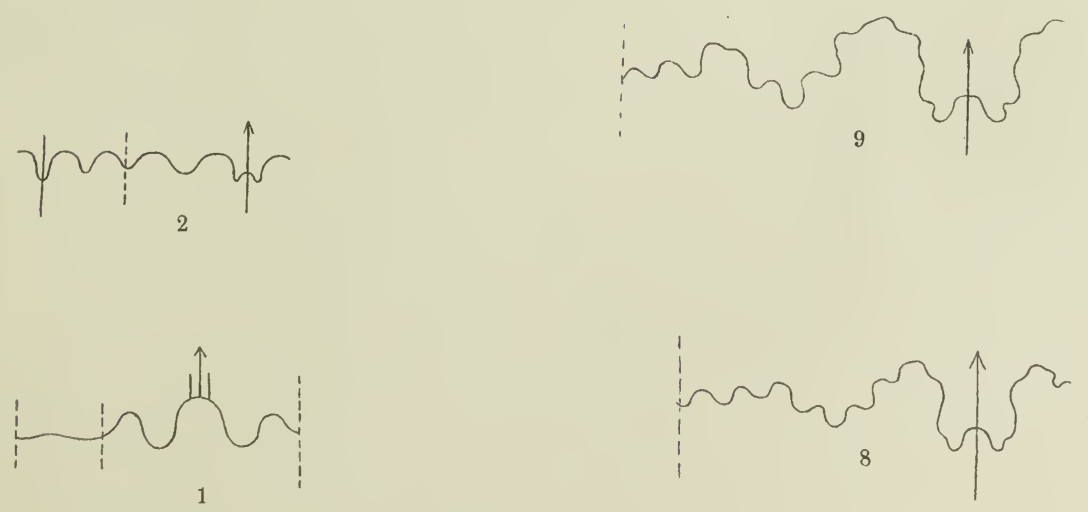




\section{EXPLANATION OF PLATE XXVIII.}

\section{Development of the Septa of Placenticeras pacificum.}

Fig. I. Placenticeras pacificum, septum at three and a sixth coils, diameter $8.50 \mathrm{~mm}$., adolescent, about end of cosmoceran stage; $\mathrm{r} / \mathrm{r}$.

Fig. 2. $P$. pacificum, septum at three and a half coils, diameter $12 \mathrm{~mm}$., Hoplites stage; $\mathrm{r} 4 / \mathrm{r}$.

Fig. 3. P. pacificum, septum at three and three-quarters coils, diameter 14.50 mm.; the septa already show placenticeran characters, although the shell is still in the Hoplites stage; 9 times enlarged.

Fig. 4. P. pacificum, septum at maturity; natural size.

Fig. 5. P. pacificum, cross-section at four coils, adolescent, diameter 20.75 mm., showing inner whorls helmet-shaped, and the transition to the compressed, flat-sided placenticeran whorl; 4 times enlarged.

Fig. 6. Septum of $P$. californicum, adolescent, cosmoceran stage, two and three-quarters coils, diameter $4.70 \mathrm{~mm}$; 13 times enlarged.

Fig. 7. Early adult septum of Diaphorites vetulonius Fucini, for comparison. (After Fucini, Pal. Ital., I896, Vol. II, Pl. XXV, fig. 8.)

Fig. 8. Septum of Placenticeras guadaloupce Roemer, for comparison. (After Roemer, Kreidebildungen von Texas, Pl. II, fig. I.) 

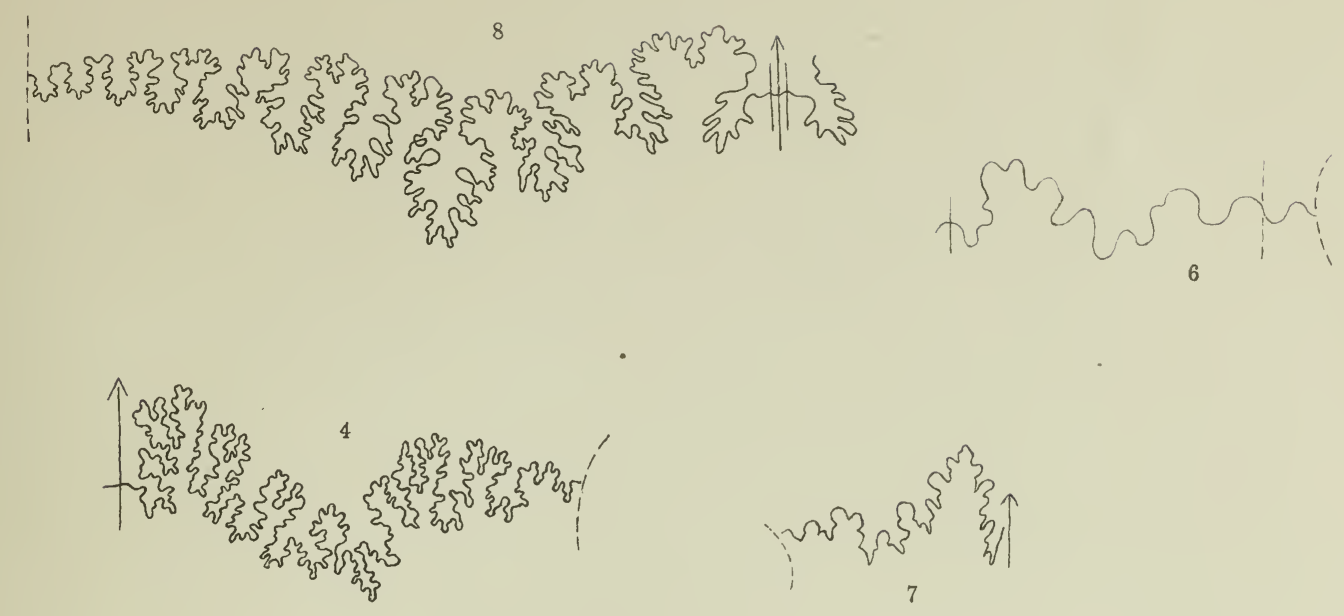

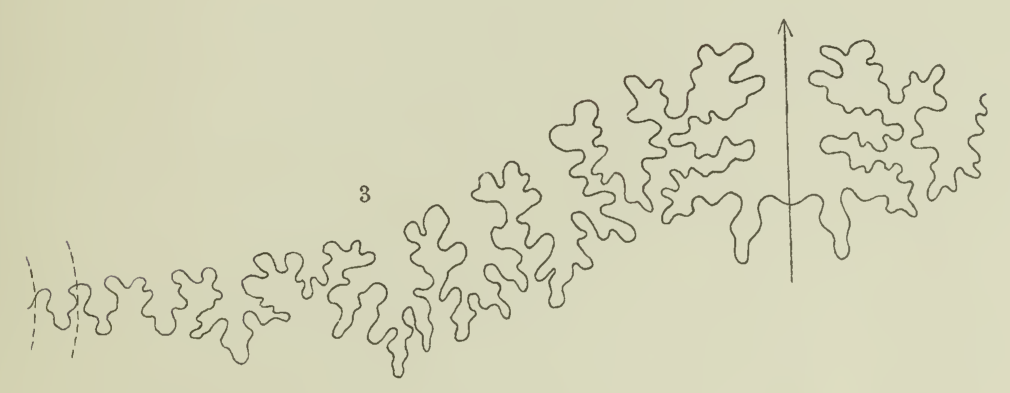

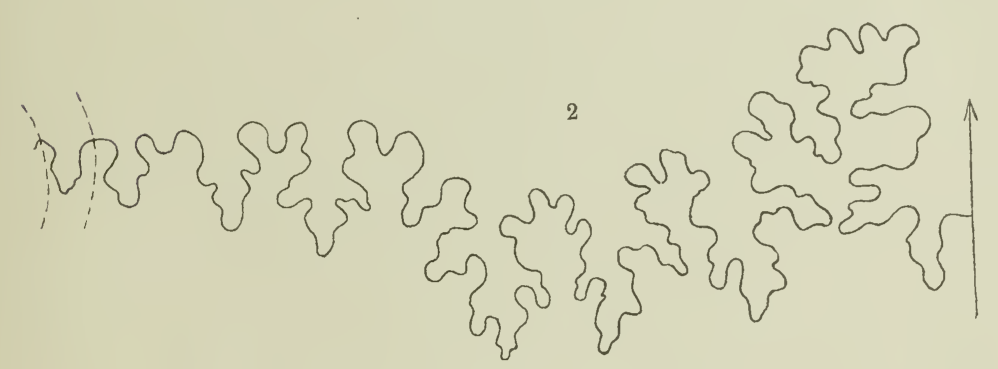

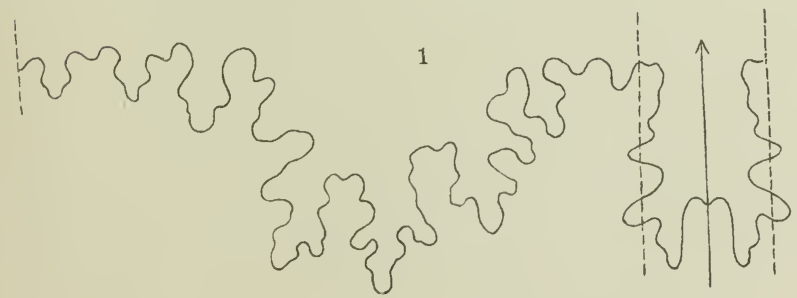

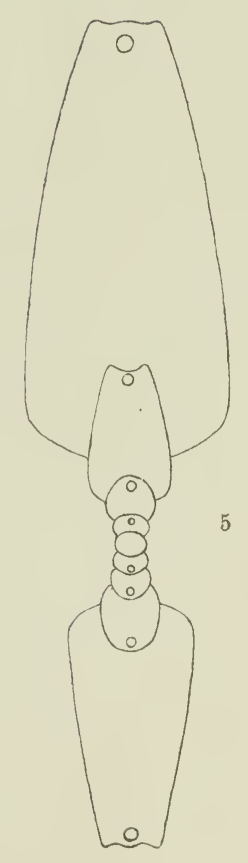

FiG'S.1-5. PLacenticeras pacifilum, Fig. E. Piacenticeras califurnicum.
Fig.7 DiaphaRiTeS VETULUNiUS Fig. 8. Piacenticeras gilamaloupa: 
UNIVERSITY OF ILLINOIS - URBANA

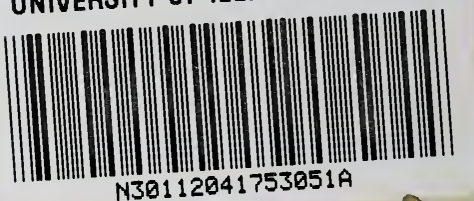

